Strapline: Original Article

Short running head: Papua New Guinea species richness

*Correspondence: Oliver Tallowin, Department of Zoology, Tel Aviv University, 69978, Tel Aviv, Israel.

Email: ollyjst@gmail.co.uk

Words in main text: 4587

Word count including abstract, main text and references 6931 


\title{
Papua New Guinea terrestrial vertebrate richness: elevation matters most for all except reptiles
}

\author{
Oliver J.S. Tallowin ${ }^{1 *}$, Allen Allison ${ }^{2}$, Adam C. Algar $^{3}$, Fred Kraus $^{4}$, and Shai Meiri ${ }^{1}$
}

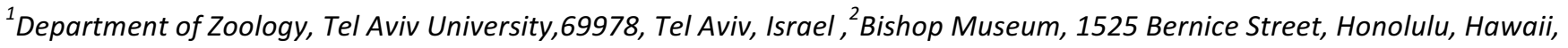
96817, USA, ${ }^{3}$ School of Geography, University of Nottingham, Sir Clive Granger Building, Nottingham NG7 2RD, UK, ${ }^{4}$ Department of Ecology and Evolutionary Biology, University of Michigan, 830 North University, Ann Arbor MI,48109, USA

\section{ABSTRACT}

Aims To examine species-richness patterns in Papua New Guinea's terrestrial vertebrates and test for geographical congruence between the four classes, and between lizard and snake subgroups. To assess the environmental correlates of Papua New Guinean terrestrial vertebrate richness, and contrast effects of varying analytical resolution and correction for spatial autocorrelation. We predict congruence in the bird, mammal and to a lesser extent amphibian richness, with weak congruence or incongruence between reptiles and the other taxonomic groups. We further predict these patterns will stem from relative or in the case of reptiles dissimilar, correlative trends with environmental predictors such as elevation and temperature.

\section{Location Papua New Guinea}

Methods Having created and updated distribution maps for reptiles, we compare them with known ranges of amphibians, birds and mammals and generate species-richness grids at quarter-, half-, and one- degree spatial resolutions. We examine congruence in species richness between vertebrate groups and between reptile subgroups. We employed spreading-dye models to simulate species richness according to eight environmental predictors and one random model. We accounted for spatial autocorrelation in all analyses.

Results Papua New Guinean amphibian, bird and mammal species richness are spatially congruent, a trend which strengthens with decreasing spatial resolution. Reptiles and the lizard and snake subgroups reveal remarkably different spatial richness trends. Elevational predictors, particularly elevational range at coarse 
resolutions, provide the strongest correlates of species richness. Whereas terrestrial vertebrate richness increases with elevation, reptile richness decreases.

Main Conclusions Congruent species-richness gradients in Papua New Guinea are observed in most terrestrial vertebrates, except reptiles. Topographic heterogeneity and associated climatic clines promote diversity in most terrestrial vertebrates but appear to strongly constrain reptile diversity. The topographical complexity and climatic stratification of tropical mountains clearly present a wealth of opportunities for diversification in most terrestrial vertebrate groups. As reptiles are strongly constrained by temperature, tropical mountains present more of a diversification barrier for them.

Key Words: cross-taxon congruence, environmental correlates, Papua New Guinea, spatial autocorrelation, spatial resolution, species richness, topographic heterogeneity. 


\section{INTRODUCTION}

Tropical regions hold the greatest species richness on the planet (Fine, 2015). Species-richness patterns and drivers within tropical regions, however, remain largely overlooked (Tuomisto et al., 2014). Analyses at continental and global scales can mask regional correlations between species richness and environmental predictors and thus fail to identify the underlying causes of regional spatial richness patterns (Qian \& Ricklefs, 2008). Previous research demonstrated temperature to be an important determinant of species-richness in temperate high-latitude regions, with primacy shifting to water availability in tropical and subtropical low-latitude regions (Hawkins et al., 2003). It was suggested future studies should focus on assessing the interaction between these two richness predictors, as well as other key factors such as environmental heterogeneity (Stein et al., 2014). Furthermore, assessing the determinants of biogeographical patterns across multiple taxonomic groups provides an insight into how these trends vary with differing attributes, such as ecology and dispersal ability (Keith et al., 2012). A comprehensive understanding of the spatial overlap of species richness, or cross-taxon congruence, particularly within tropical regions, is crucial for efficient conservation planning and assessing the impacts of climate change (Grenyer et al., 2006; Qian \& Ricklefs, 2008).

Broad-scale global analyses typically reveal similar species-richness patterns across vertebrate taxa (Grenyer et al., 2006; Qian \& Ricklefs, 2008). However, considerable variation in vertebrate congruence at continental and regional scales has also been observed, particularly between lizards and other taxa (Powney et al., 2010; Lewin et al., 2016). Cross-taxon congruence is expected when taxa respond similarly to environmental determinants or share large-scale diversification, colonisation and extinction rates (Qian \& Ricklefs, 2008). The spatial scale at which range map based richness patterns are examined likely influences perceived patterns and drivers of richness (Rahbek, 2005; Hurlbert \& Jetz, 2007; Field et al., 2009), especially within the tropics (Jetz et al., 2008). Despite the recognition of scale effects, fine-scale analyses and crosstaxon comparisons of richness determinants are uncommon (Belmaker \& Jetz, 2011). While climatic determinants are strongest at coarse scales, processes such as biotic and abiotic filters regulating local 
community assemblages may provide better explanations for fine-grained richness (Whittaker et al., 2001; Belmaker \& Jetz, 2011).

Attempts to explain broad-scale species-richness gradients generally focus on predictors such as energy availability, environmental heterogeneity, study area and evolutionary time (Currie, 1991; Rahbek \& Graves, 2001; Hawkins et al., 2003; Field et al., 2009). The energy-richness hypothesis (Wright, 1983) proposes that richness is limited by resource availability. Ambient energy is noted as a principle limiting factor for richness at high cold latitudes, with water availability a strong richness determinant at low warm latitudes (Hawkins et al., 2003). Although ambient energy and water availability may directly constrain richness, their interaction is purported to affect distribution patterns indirectly through plant productivity (Field et al., 2009). Plant productivity may influence animal-species richness through increased potential biomass, but it may also be consistent with the resource-speciation hypothesis in providing a greater diversity of resource types supporting more specialist species (Kaspari et al., 2000; Hurlbert, 2004). Tropical regions have the highest rates of net primary productivity (npp; Gillman et al., 2014); a factor thought to cause a trophic cascade of resource abundance, resulting in diversity peaks (Currie, 1991; O’Brien, 1998).

Environmental and topographic heterogeneity (i.e., elevational range) are purported to be among the most important factors influencing species richness (Stein et al., 2014), especially at medium to fine spatial scales (Field et al., 2009). Topographic heterogeneity is thought to increase the number of habitat types and resources available, which in turn increases the potential niche space allowing more species to coexist (Stein et al., 2014). Topographically heterogeneous regions are thought to be particularly important for narrowly ranging endemics by acting as both cradles and museums of biodiversity (Fjeldså et al., 2012). The cradle hypothesis posits that increased range in topography and climate will create greater potential for speciation by isolation and divergent adaptation. According to the museum hypothesis, refuge potential in elevationally diverse regions is greater during periods of climatic fluctuation, increasing species persistence (Currie, 1991; Tews et al., 2004). Topography is suggested to influence richness most in regions experiencing the greatest climatic stability over the longest period of time, such as those in the tropics (Fine, 2015). 
Indeed, broad-scale studies have often highlighted the significance of tropical montane regions for species diversity (Orme et al., 2005; Cadena et al., 2011). At large spatial scales species turnover in montane regions, caused by environmental heterogeneity and niche availability absent in homogenous landscapes, inflates species richness (McCain \& Beck, 2016).

New Guinea is among the most biologically diverse regions on the planet (Brooks et al., 2006). The exceedingly rich vertebrate assemblage ( $5 \%$ of the world's terrestrial vertebrate species on less than $0.2 \%$ of the Earths land surface) is thought to be the product of the island's large size $\left(785,753 \mathrm{~km}^{2}\right)$, tropical climate, complex geological history and extensive mountain ranges (Allison, 2009; Shearman and Bryan, 2011). New Guinea has a remarkable degree of tectonic complexity (Baldwin et al., 2012), resulting in extensive mountain uplift (over $31 \%$ of its mainland area is above $1,000 \mathrm{~m}$, Allison, 2009). These extensive and often isolated mountain ranges produce high levels of range-restricted species. The climate of much of New Guinea is weakly seasonal, with temperature variation largely influenced by elevation, although the savannah areas have a distinct dry season and reduced precipitation overall ( $1000-1500 \mathrm{~mm}$ annual rainfall; Allison, 2009). Roughly, two-thirds of the island is covered in broadleaf forests, mostly rain forest, which receive from 2000 to more than $10,000 \mathrm{~mm}$ of rainfall annually and lack a pronounced dry season. As the fauna on the eastern side of New Guinea, in the country of Papua New Guinea (PNG), has been more thoroughly surveyed (Heads, 2002), we restrict our study on the terrestrial vertebrates in the country of PNG. The many offshore islands that also comprise a significant portion of PNG are not included in our analyses, so it should be understood henceforth that our use of "PNG" refers only to the mainland New Guinea portion of that country.

We assess species richness, cross-taxon congruence and environmental correlates of PNG's terrestrial vertebrates. To determine the effect of spatial scale on these relationships, we conduct analyses at three spatial resolutions. We predict that the aseasonal tropical climate will result in the highest terrestrial-vertebrate richness predominantly in montane regions. Sharp climatic clines coupled with decreasing connectivity at higher altitudes, are expected to promote species' elevational segregation 
(Janzen, 1967; Ghalambor et al., 2006) and increase the number of high-elevation range-restricted local endemics. This trend will be most evident in taxa with comparatively poor dispersal ability, such as amphibians. We further predict that PNG amphibian richness will be less constrained by water availability than observed in other, more water-limited, regions (Buckley \& Jetz, 2007). While amphibians' physiological and ecological requirements for water (Feder \& Burggren, 1992) will remain fundamentally the same, the extremely high degree of precipitation across most of PNG will reduce its level of constraint across the region. We predict that PNG bird and mammal species richness will be strongly positively correlated, exhibiting concordant trends to the environmental predictors due to the equivalent physiology and energetic requirements of endotherms (Grenyer et al., 2006). We predict that PNG reptiles will show the greatest degree of disparity in richness patterns. Reptiles are strongly constrained by temperature due to their physiology and they fundamentally differ from amphibians in their ability to control water loss with dry and scaly skin (Adolph \& Porter, 1993). We predict reptile richness will peak in warm lowland regions, thus the ectothermic groups should display incongruent species-richness patterns compared with congruent endothermic richness.

\section{MATERIALS AND METHODS}

\section{Species geographical range data}

We compiled geographical range data for all 232 PNG native mainland reptile species using ArcGIS 10.0, following the taxonomy of Uetz and Hošek (2015), but including three lizards (Cryptoblepharus novaeguineae, Gehyra baliola, and Sphenomorphus anotus) considered valid by the IUCN Melanesian Reptile Working Group, 2014 (see Appendix S1 and S2 in Supporting Information). We obtained reptile range maps from the Bishop Museum Pacific Biological Survey Project and during the IUCN Melanesian Reptile Redlist Project (July, 2014). We converted all point-locality data to polygons using a $10 \mathrm{~km}^{2}$ buffer (radius $=1.72$ km), in accordance with IUCN mapping standards (http://www.amphibians.org/wpcontent/uploads/2013/09/Red-List-Mapping-standards-ARLA-Jan2014-web-version.pdf). To assess trends 
in species richness within reptiles, we divided PNG reptiles into lizards $(n=150)$ and snakes $(n=68)$, omitting crocodiles $(n=2)$ and turtles $(n=12)$ due to their low species numbers. Following the taxonomy of Frost (2015), we obtained ranges for 217 of the 275 PNG amphibian species-ranges from the IUCN (2014) and digitized the remaining 58 maps ourselves (see Appendices S1 and S2). We obtained range maps for PNG's 635 breeding-bird species from BirdLife International and NatureServe (2014) and amended 64 of these according to the taxonomy of Pratt and Beehler (2014; see Appendix S1). We obtained range maps for 232 PNG mammal species, 219 were obtained from IUCN (2012) and 13 maps for recently described species were digitized by us (see Appendices S1 and S3).

Species richness for each terrestrial vertebrate group was obtained by collating range maps per group and combining them with three gridded layers of Papua New Guinea (see Appendix S4). Grid cells were either $25 \times 25 \mathrm{~km}^{2}(n=620), 50 \times 50 \mathrm{~km}^{2}(n=160)$, or $100 \times 100 \mathrm{~km}^{2}(n=41)$. Equivalence in grid-cell area was ensured using a Behrmann equal-area projection; wherein grid cells areas were $625,2,500$ or $10,000 \mathrm{~km}^{2}$. For convenience, we refer to these grid layers as 'quarter-degree grid', 'half-degree grid' and 'one-degree grid', as they approximate to these sizes. We omitted grid cells with $<50 \%$ land area to negate potential speciesarea relationships.

\section{Environmental data}

Three climatic predictors (temperature, precipitation and net primary productivity) and one topographic predictor (elevation) were used to derive eight environmental predictors (see Appendix S5). Temperature and precipitation data were obtained from the PNG Resource Information System ( $3^{\text {rd }}$ Edition; Bryan \& Shearman, 2008) and used to produce mean-annual and annual-range measures for both temperature (a proxy for ambient energy availability) and precipitation (a proxy for water availability). Net primary productivity (npp) data were obtained from Imhoff et al. (2004) and used as a proxy for rate of biomass production in primary producers (Hurlbert, 2004). Insufficient variance in npp heterogeneity precluded its use as a richness predictor. Elevational data were obtained from the PNG Resource Information 
System ( $3^{\text {rd }}$ Edition; Bryan \& Shearman, 2008) and used to create three topography predictors: mean elevation, elevational range (maximum - minimum elevation per grid cell) and a 'mid-elevation' predictor (see below). The 'mid-elevation' model predicts that species richness has a unimodal relationship with elevation, thus within a given grid cell richness will increase with the proportion of area at Papua New Guineas elevational mid-point. The function to simulate this follows the formula:

$$
E_{\text {mid }}=1-\left(\left(\left|E_{i}-E_{j m i d}\right|\right) / E_{j m i d}\right)
$$

where ${ }_{j}$ represents the total gridded domain of PNG, and ${ }_{i}$ a given cell within the grid. $E_{i}$ represents the mean elevation in cell $i$, and $E_{j m i d}$ is half the difference between the maximum and minimum mean elevation recorded in grid $_{\mathrm{j}}$.

\section{Simulation models}

Richness patterns are typically investigated through curve-fitting analysis (Rahbek et al., 2007) and as such cannot model species ranges directly or generate quantitative predictions of species richness (Gotelli et al., 2009). Spreading-dye models (termed "Geometric constraint models" in Jetz and Rahbek, 2001) were developed as an alternative method for assessing richness gradients in heterogeneous landscapes. These spatially explicit models can simulate speciation, dispersal and extinction of species in heterogeneous landscapes (Gotelli et al., 2009). Spreading-dye models reconstruct distributions by assigning cells to a species' range within the gridded domain. After the initial cell has been selected the range is allowed to expand to adjacent cells, with the cell number in each species' predicted range equivalent to its observed range. The initial grid cell and subsequent adjacent cell selection can either occur stochastically, with all grid cells equal in selection probability, or be weighted according to underlying environmental predictor values across the gridded domain (Storch et al., 2006; Rahbek et al., 2007; Szabo et al., 2009).

To simulate species richness according to our predictors, we used spreading-dye models at a quarter, half- and one-degree grid scale (Jetz \& Rahbek, 2001; Storch et al., 2006). For each terrestrial vertebrate group we developed nine species-richness simulation models, eight simulation models derived from 
environmental predictors and one null model. The null model specifies a single geographic origin for each species, and allows each range to spread cohesively and randomly within the gridded domain (Gotelli et al., 2009). Simulations were modified to assess the role of environmental gradients on species richness by weighting cells according to the predictor values (Storch et al., 2006; Rahbek et al., 2007; Szabo et al., 2009). The gridded predictors: mean elevation, elevational range, mean annual npp, mean annual temperature, annual temperature range, mean annual precipitation and annual precipitation range were rescaled to between 0 and 1 , using minimum and maximum values for each predictor. This ensured that a given proportional change resulted in an equivalent change in cell selection probability across all environmental predictors (Rangel et al., 2007). The relative probability of initial cell and subsequent adjacent cell selection was determined by variation in the environmental predictor values. Thus environmental determinism per cell ranged from completely random $(i=0)$ to strongly deterministic $(i=1)$. Simulated terrestrial-vertebrate species richness, derived from the nine predictors at three spatial resolutions, was carried out 999 times for each group, and the gridded mean species richness calculated from all models.

\section{Statistical analysis}

All statistical analyses were carried out in R 3.3.0 (R Development Core Team, 2016). Cross-taxon congruence among PNG terrestrial-vertebrate group richness was initially assessed using Pearson's correlation coefficient; however, non-independence in the spatial data was detected using Moran's I (see Appendix S6). Spatial autocorrelation arises when neighbouring locality values in spatial data are more similar than expected by chance (Legendre, 1993), leading to increased type-1 error rates and incorrect parameter estimates (Lennon, 2000). To account for spatial autocorrelation we used Dutilleul's modified $t$ test (Dutilleul et al., 1993), provided in the package SpatialPack (Osorio \& Vallejos, 2014).

To identify the strongest environmental correlates of each PNG terrestrial vertebrate group, we regressed observed species richness against richness simulated by the eight environmental predictors and the single stochastic predictor. We initially conducted ordinary least squares (OLS) regression, then 
accounted for spatial autocorrelation in model residuals by using simultaneous autoregressive (SAR) models (Kissling \& Carl, 2008), provided in the package spdep (Bivand \& Piras, 2015). The spatial structure was specified as the eight nearest neighbours to each cell, and neighbour cells were weighted according to the row-standardized coding scheme. We assessed the relative explanatory power in the OLS and SAR models using Akaike's Information Criterion (AIC $)$.

\section{RESULTS}

\section{Species richness}

PNG bird and mammal richness have generally concordant patterns at the quarter-degree grid scale, whereas amphibian and reptile richness patterns are distinct from these and from each other (Fig. 1). Amphibian richness (13 - 55 species per grid cell, mean $27 \pm 8$ SD; Fig. 1) peaks within the Central Highlands and northwestern Bewani and Torricelli mountain ranges, with less pronounced peaks on the southeastern Owen Stanley mountain range. Lowest amphibian richness occurs in the southwestern Trans-Fly, northwestern Sepik, and coastal lowland areas. Bird richness reveals a strong affinity to the Papuan peninsula, with greatest richness bordering the Owen Stanley mountain ranges and lowest within the interior of the Central Highlands, southwestern Trans-Fly and northwestern Sepik lowlands (133 - 411 species per grid cell, mean: $289 \pm 47$; Fig. 1). Mammal richness peaks trace the Central and southern Owen Stanley Mountains periphery, with lowest richness in the Trans-Fly and Sepik lowlands (35 - 118 species per grid cell, mean: $76 \pm 21$ ). Reptile richness peaks occur within the lowlands of the Trans-Fly, Huon Gulf and southcentral Papuan Peninsula, with richness decreasing towards the major mountain range interiors (11 - 89 species per grid cell, mean $56 \pm 15$; Fig. 1). Dividing PNG reptiles into lizards $(n=150)$ and snakes $(n=68)$ reveals strikingly different richness peaks (Fig. 1). Lizard richness peaks in northern lowland areas along the Huon Gulf and northwest West Sepik Province, whereas snake richness peaks in the lowlands of the TransFly and south-central Papuan Peninsula. 
Cross-taxon congruence between PNG amphibian, bird and mammal species richness is positive irrespective of spatial autocorrelation or resolution (Table 1). Mammal richness exhibits the strongest degree of congruence with amphibian and bird richness, across the three spatial resolutions (Pearson's $r=0.61$ $0.87, P<0.01)$. In contrast, once corrected for spatial autocorrelation, reptile richness is not significantly correlated with amphibian, bird or mammal richness at any of the spatial resolutions. Lizard and snake richness largely exhibit no correlation with the other three terrestrial vertebrate groups. Lizard and bird richness are positively correlated at the quarter-degree resolution (Pearson's $r=0.39, P<0.01$ ), however, this relationship becomes insignificant at the coarser resolutions. A positive correlation between lizard and snake richness, also diminishes with decreasing spatial resolution (Pearson's $r=0.69[P<0.01], 0.54[P<0.01]$ and $0.36[P 0.02]$ at the quarter-degree, half-degree and one-degree resolutions).

\section{Simulated environmental predictors}

Our analyses reveal that elevation provides the best predictor of PNG terrestrial-vertebrate richness (Table 2 and see Appendix S7). Correcting for spatial autocorrelation affected the variance explained by each predictor model. This altered the best-fit predictor models for amphibian and mammal richness at the finest resolutions and for birds at the two coarser resolutions. Spatial resolution similarly affects the best-fit predictor models, primarily between the quarter- and half degree for all terrestrial vertebrates except reptiles. PNG reptile richness exhibits a distinct, negative correlation with mean elevation at quarter-degree (OLS $r^{2}=0.48, P<0.01 ;$ SAR Naglekerke $\left.r^{2}=0.71, P<0.01\right)$ and half-degree resolutions (OLS $r^{2}=0.25, P<0.01$; SAR Naglekerke $\left.r^{2}=0.49, P<0.01\right)$. At the quarter-degree resolution, PNG bird richness is strongly correlated with the mid-elevation richness model (OLS $r^{2}=0.20, P<0.01$; SAR Naglekerke $r^{2}=0.63, P<0.01$ ). Variance in amphibian richness is best explained by temperature range (OLS $r^{2}=0.42, P<0.01$; SAR Naglekerke $r^{2}=$ $0.80, P<0.01)$, and mammal richness by elevational range (OLS $r^{2}=0.76, P<0.01 ;$ SAR Naglekerke $r^{2}=0.88$, $P<0.01)$. Further, elevational range best explains the variance in amphibian, bird and mammal richness at both the half- and one-degree resolution, following correction for spatial autocorrelation. The stochastic 
spreading-dye and net-primary-productivity richness models consistently provide the worst predictors of PNG terrestrial vertebrate species richness.

\section{DISCUSSION}

This study provides a comprehensive assessment of the biogeographical patterns of species richness for terrestrial-vertebrates in Papua New Guinea, a remarkably diverse but understudied region. Our analyses reveal congruent richness patterns in all Papua New Guinea terrestrial vertebrates except for reptiles and the constituent lizard and snake groups. Our findings are generally consistent with the cross-taxon congruence observed in most groups at the global scale (Grenyer et al., 2006; Qian \& Ricklefs, 2008), and reptiles being outliers within regions such as Australia (Powney et al., 2010), and Africa (Lewin et al., 2016). As in previous studies (Grenyer et al., 2006; Belmaker \& Jetz, 2011) spatial resolution influenced the degree of congruence among richness patterns for PNG amphibians, birds and mammals, but had no effect on reptile incongruence. These congruent versus contrasting patterns are evidently linked to the underlying abiotic and biotic factors governing each species' distribution, a trend increasingly apparent at finer spatial scales.

Climatic variables are frequently considered to provide the strongest predictors of broad-scale species richness (Hawkins et al., 2003; Field et al., 2009), while other studies have suggested topographic heterogeneity measures may strongly regulate species richness gradients, especially at small spatial scales (Kerr \& Packer, 1997; Whittaker et al., 2001; Ricklefs, 2006; Rahbek et al., 2007; Stein et al., 2014). Belmaker \& Jetz (2011) noted that measures of global amphibian, bird and mammal richness patterns display contrasting relationships with climate, but similar relationships with topographical heterogeneity. The primacy of topographical heterogeneity in predicting species richness is particularly evident in high-energy regions such as the tropics (Orme et al., 2005; Grenyer et al., 2006; Davies et al., 2007; Kreft \& Jetz, 2007; Thomas et al., 2008; Qian, 2010). Our analyses reveal that elevational range strongly correlates with PNG amphibian, bird and mammal richness at coarser spatial resolutions. Furthermore, in accordance with 
Belmaker \& Jetz (2011), we show that all terrestrial vertebrates, except reptiles, display similar topographical-heterogeneity-richness slopes (Table 2). We thus provide evidence for the existence of elevational-based mechanisms promoting species richness through high levels of persistence and speciation in PNG amphibian, bird and mammal groups. In contrast, reptile richness is strongly constrained by elevation, with peaks in the warmer lowlands, suggesting that these are central regions for reptile diversification and persistence.

Our analyses reveal PNG reptile species richness is strongly constrained by elevation and, as predicted, is positively correlated with temperature (Currie, 2001; Whittaker et al., 2007; Qian, 2010), probably through direct effects on life-history traits (Meiri et al., 2013). Adaptation to survive in waterlimited regions has enabled reptiles to persist in the southern Trans-Fly and Port Moresby savannah areas. Richness peaks in these areas likely reflects the accumulation of numerous Australian reptile species, largely wide-ranging snakes, during the land connections of the last series of glaciations. Except for reptiles, vertebrate species richness in savannah is generally lower than in closed-canopy wet forest, suggesting decreased competition and predation pressure may also enable a greater diversity of reptiles to exist in these areas (Sweet \& Pianka, 2007). The northern reptile richness peaks, dominated by lizards, likely represent important transition zones between once-geographically distinct assemblages and thus contain a high degree of phylogenetic diversity.

Although elevation per se is unlikely to cause species-richness gradients, topographic heterogeneity likely acts as a surrogate for precise local climatic conditions, such as temperature and precipitation, purportedly strong determinants of species richness (Qian, 2010). Interplay among factors such as slope and aspect will increase the range of climatic conditions in geographically proximate mountains, thus increasing diversity in taxa with slightly different climatic envelopes. Climatic stratification along tropical elevational gradients purportedly limits the elevational extent to which any particular species' physiological profile can function (Janzen, 1967; Ghalambor et al., 2006). Turnover in elevational plant communities led to elevational range being commonly used as a proxy for habitat heterogeneity, with this inferred increased habitat 
diversity purported to allow for increased sampling of habitat specialists (Rahbek \& Graves, 2001; Davies et al., 2007, but see Hortal et al., 2013). It is likely that these processes have been highly influential in promoting amphibian, bird and mammal diversity in PNG's topographically complex regions. Whereas, reptile richness may be limited along mountain slopes by factors such as restricted access to solar radiation caused by increased humidity, vegetation and cloud cover (McCain, 2010).

Climatic predictors such as temperature, precipitation and primary productivity, are frequently reported as strong correlates of broad-scale vertebrate richness patterns (Jetz \& Rahbek 2002; Currie et al., 2004; but see Adler et al., 2011). However, these predictors consistently had lower effects sizes on PNG terrestrial vertebrate richness, compared with the topographic predictors (Table 2). In particular, npp performed poorly across all taxonomic groups and analytical resolutions. This indicates that these climatic predictors do not constrain species richness to the same degree as in higher-latitude regions. The stochastic spreading-dye model, essentially equivalent to a mid-domain effect which predicts higher richness at the centre of an island or continent (Gotelli et al., 2009), also performed poorly for all taxa, except for reptiles where it was reversed (reptiles being rich at coastal lowland areas), probably reflecting the effects of temperature. Cross-scale variation in predictor primacy and the effect of spatial autocorrelation, highlight the need for careful examination of broad-scale biogeographical data. Failure to do so can affect the study inferences, as illustrated in this study (Table 1 - 2).

Environmental-predictor effect sizes, in both the OLS and SAR models, for PNG terrestrial vertebrates were lowest in reptiles at the one-degree resolution (Table 2). This indicates that extraneous factors, such as differing affinities to geological terranes, may be influencing reptile richness patterns in PNG. New Guinea's complex geotectonic history and major mountain-building events are purported to be a crucial factor shaping the regions biotic diversity (Georges et al., 2014; Toussaint et al., 2014). In particular, environmental change during orogenesis is likely to have driven diversification in New Guinea (Toussaint et al., 2014). This may explain the high alpha- and beta-diversity of amphibians, birds and mammals in the montane regions (see Appendix S8). Once-isolated terranes that are now accreted along New Guinea's 
northern coast have also been important allopatric speciation centres, especially for amphibians and reptiles.

We suspect that comparable environmental conditions and biotic diversity across New Guinea will result in equivalent cross-taxon congruence and environmental-richness correlates to those observed by us in PNG. Although the New Guinean biota remains poorly known compared to many other parts of the world, the overall patterns of biotic distribution and richness, particularly within Papua New Guinea, are reasonably well known and are unlikely to change appreciably as new species are discovered and named (Allison \& Tallowin, 2015). We minimised distributional errors in PNG species by using expert-drawn range maps, combining both observation and speculative data. Expert-drawn maps are less susceptible to underestimation of true range size compared with point-observation data and do not grossly overestimate a species' range and elevational limits, as seen in extent-of-occurrence range maps (Hulbert \& Jetz, 2007; Rocchini et al., 2011). Over-estimation of species ranges is particularly influential in narrow ranging species found in low tropical latitudes (Jetz et al., 2008).

The congruent spatial-richness patterns identified among PNG amphibian, bird and mammal species, and the incongruent reptile richness patterns, have important implications for regional conservation. Protected areas targeted towards high species richness in a single taxon are likely to provide coverage for a range of terrestrial vertebrate species. However, such protected areas would fail to capture areas of high reptile richness. Disparity in reptile species richness, caused by their divergent environmental requirements, suggest that reptile-specific conservation approaches will provide the most effective method for preserving their regional centres of diversity. As reptile diversification centres correspond to important biogeographical regions, such as the Trans-Fly and Port Moresby savannah, conservation efforts targeting reptile hotspots will also have the added benefit of preserving these unique regions. Effective conservation strategies in PNG will ultimately require additional assessment of congruence patterns for range-restricted and threatenedspecies combined with a geographical understanding of the major threats to terrestrial vertebrates (Shearman \& Bryan, 2010). However, these assessments will greatly benefit from further research 
addressing the taxonomic and distribution shortfalls particularly evident in groups, such as amphibians (Allison, 2009), and reptiles (Meiri, 2016). By revealing the spatial species richness patterns in PNG's terrestrial vertebrates and identifying their strongest environmental correlates, we provide baseline information, which may contribute to conservation planning in PNG.

\section{ACKNOWLEDGEMENTS}

We thank the IUCN Melanesian Reptile Working Group members: Fred Parker, Glenn Shea, Mark O'Shea, Neil Cox, Paul Oliver and Philip Bowles, in reviewing the New Guinea reptile distribution maps. We are grateful to Phil Shearman and Jane Bryan for providing the PNG environmental data. We thank Alex Slavenko, Amir Lewin, Jonathan Belmaker and Thane Pratt for insightful comments on earlier versions of this manuscript. We are grateful to Maria Novosolov, Uri Obolski and Ohad Lewin-Epstein for advice in data analysis and assistance with the spreading-dye simulation models. This research was supported by a BSF grant \# 2012143 to AA and SM.

\section{REFERENCES}

Adler, P.B., Seabloom, E.W., Borer, E.T., Hillebrand, H., Hautier, Y., Hector, A., Harpole, W.S., O’Halloran, L.R., Grace, J.B. \& Anderson, T.M. (2011) Productivity is a poor predictor of plant species richness. Science, 333, 1750-1753.

Adolph, S.C. \& Porter, W.P. (1993) Temperature, activity, and lizard life histories. The American Naturalist, 142, 273-295.

Allison, A. (2009) New Guinea, biology. Encyclopedia of Islands. University of California Press, Berkeley.

Allison, A. \& Tallowin, O.J.S (2015) Occurrence and Status of Papua New Guinea Vertebrates. The State of the Forests of Papua New Guinea 2014: Measuring Change Over Period 2002-2014. (ed. by J.E. Bryan, \& P.L. Shearman), pp 87-101. Published by the University of Papua New Guinea, Port Moresby. 
Baldwin S.L., Fitzgerald P.G., \& Webb L.E. (2012) Tectonics of the New Guinea region. Annual Review of Earth and Planetary Sciences, 40, 495-520.

Belmaker, J. \& Jetz, W. (2011) Cross-scale variation in species richness-environment associations. Global Ecology and Biogeography, 20, 464-474.

BirdLife International and NatureServe (2014) Bird species distribution maps of the world. BirdLife International, Cambridge, UK and NatureServe, Arlington, USA. Available from: http://www.birdlife.org/datazone/info/spcdownload (Accessed 11 May 2015)

Bivand, R. \& Piras, G. (2015). Comparing Implementations of Estimation Methods for Spatial Econometrics. Journal of Statistical Software, 63, 1-36. Available at: http://www.jstatsoft.org/v63/i18/.

Brooks, T.M., Mittermeier, R.A., da Fonseca, G.A., Gerlach, J., Hoffmann, M., Lamoreux, J.F., Mittermeier, C.G., Pilgrim, J.D. \& Rodrigues, A.S. (2006) Global biodiversity conservation priorities. Science, 313, 58-61.

Bryan, J. E., \& Shearman, P. L. (2008). Papua New Guinea resource information handbook, Third edition. University of Papua New Guinea, Port Moresby.

Buckley, L.B. \& Jetz, W. (2007) Environmental and historical constraints on global patterns of amphibian richness. Proceedings of the Royal Society B: Biological Sciences, 274, 1167-1173.

Cadena, C.D., Kozak, K.H., Gomez, J.P., Parra, J.L., McCain, C.M., Bowie, R.C., Carnaval, A.C., Moritz, C., Rahbek, C., Roberts, T.E., Sanders, N.J., Schneider, C.J., VanDerWal, J., Zamudio, K.R. \& Graham, C.H. (2011) Latitude, elevational climatic zonation and speciation in New World vertebrates. Proceedings of the Royal Society B: Biological Sciences, 279, 194-201.

Currie, D.J. (1991) Energy and large-scale patterns of animal-and plant-species richness. The American Naturalist, 137, 27-49. 
Currie, D.J. \& Kerr, J.T. (2008) Tests of the mid-domain hypothesis: a review of the evidence. Ecological Monographs, 78, 3-18.

Davies, R.G., Orme, C.D.L., Storch, D., Olson, V.A., Thomas, G.H., Ross, S.G., Ding, T.-S., Rasmussen, P.C., Bennett, P.M. \& Owens, I.P. (2007) Topography, energy and the global distribution of bird species richness. Proceedings of the Royal Society of London B: Biological Sciences, 274, 1189-1197.

Dutilleul, P. (1993) Modifying the $t$ test for assessing the correlation between two spatial processes. Biometrics, 49, 305-314.

Feder, M.E. \& Burggren, W.W. (1992) Environmental physiology of the amphibians. University of Chicago Press, Chicago.

Field, R., Hawkins, B.A., Cornell, H.V., Currie, D.J., Diniz-Filho, J.A.F., Guégan, J.F., Kaufman, D.M., Kerr, J.T., Mittelbach, G.G. \& Oberdorff, T. (2009) Spatial species-richness gradients across scales: a meta-analysis. Journal of Biogeography, 36, 132-147.

Fine, P. (2015) Ecological and evolutionary drivers of geographic variation in species diversity. Annual Review of Ecology, Evolution, and Systematics, 46, 369-392.

Fjeldså, J., Bowie, R.C. \& Rahbek, C. (2012) The role of mountain ranges in the diversification of birds. Annual Review of Ecology, Evolution, and Systematics, 43, 249-265.

Frost, D. (2015) Amphibian Species of the World: An Online Reference, ver. 6.0, American Museum of Natural History, New York. Available from: http://research.amnh.org/herpetology/amphibia/ (Accessed 1 October 2015)

Georges, A., Zhang, X., Unmack, P., Reid, B.N., Le, M. \& McCord, W.P. (2014) Contemporary genetic structure of an endemic freshwater turtle reflects Miocene orogenesis of New Guinea. Biological Journal of the Linnean Society, 111, 192-208. 
Ghalambor, C.K., Huey, R.B., Martin, P.R., Tewksbury, J.J. \& Wang, G. (2006) Are mountain passes higher in the tropics? Janzen's hypothesis revisited. Integrative and Comparative Biology, 46, 5-17.

Gillman, L.N., Wright, S.D., Cusens, J., McBride, P.D., Malhi, Y. \& Whittaker, R.J. (2014) Latitude, productivity and species richness. Global Ecology and Biogeography, 24, 107-117.

Gotelli, N.J., Anderson, M.J., Arita, H.T., Chao, A., Colwell, R.K., Connolly, S.R., Currie, D.J., Dunn, R.R., Graves, G.R. \& Green, J.L., J. Arvid, Y.-H.J. Grytnes, W. Jetz, S.K. Lyons, C.M. McCain, A.E. Magurran, C. Rahbek, T.F.L.V.B. Rangel, J. Soberón, C.O. Webb, M.R. Willig (2009) Patterns and causes of species richness: a general simulation model for macroecology. Ecology Letters, 12, 873886.

Grenyer, R., Orme, C.D.L., Jackson, S.F., Thomas, G.H., Davies, R.G., Davies, T.J., Jones, K.E., Olson, V.A., Ridgely, R.S. \& Rasmussen, P.C. (2006) Global distribution and conservation of rare and threatened vertebrates. Nature, 444, 93-96.

Hawkins, B.A., Field, R., Cornell, H.V., Currie, D.J., Guégan, J.-F., Kaufman, D.M., Kerr, J.T., Mittelbach, G.G., Oberdorff, T. \& O'Brien, E.M. (2003) Energy, water, and broad-scale geographic patterns of species richness. Ecology, 84, 3105-3117.

Heads, M. (2002) Regional patterns of biodiversity in New Guinea animals. Journal of Biogeography, 29, 285-294.

Hurlbert, A.H. (2004) Species-energy relationships and habitat complexity in bird communities. Ecology Letters, 7, 714-720.

Hurlbert, A.H. \& Jetz, W. (2007) Species richness, hotspots, and the scale dependence of range maps in ecology and conservation. Proceedings of the National Academy of Sciences, USA, 104, 1338413389. 
Imhoff, M.L., Bounoua, L., Ricketts, T., Loucks, C., Harriss, R. \& Lawrence, W.T. (2004) Global patterns in net primary productivity. Data distributed by the Socioeconomic Data and Applications Center (SEDAC). Available at: http://sedac.ciesin.columbia.edu/es/hanpp.html

IUCN (2012) IUCN Red List of Threatened Species. Version 2012.1. Available at: http://www.iucnredlist.org (Accessed 10 November 2014)

IUCN (2014) The IUCN Red List of Threatened Species. Version 2014.1. Available at: http://www.iucnredlist.org (Accessed 12 June 2014)

Janzen, D.H. (1967) Why mountain passes are higher in the tropics. The American Naturalist, 101, 233249.

Jetz, W. \& Rahbek, C. (2001) Geometric constraints explain much of the species richness pattern in African birds. Proceedings of the National Academy of Sciences, USA, 98, 5661-5666.

Jetz, W. \& Rahbek, C. (2002) Geographic range size and determinants of avian species richness. Science, 297, 1548-1551.

Jetz, W., Sekercioglu, C.H. \& Watson, J.E. (2008) Ecological correlates and conservation implications of overestimating species geographic ranges. Conservation Biology, 22, 110-119.

Kaspari, M., O'Donnell, S. \& Kercher, J.R. (2000) Energy, density, and constraints to species richness: ant assemblages along a productivity gradient. The American Naturalist, 155, 280-293.

Keith, S.A., Webb, T.J., Böhning-Gaese, K., Connolly, S.R., Dulvy, N.K., Eigenbrod, F., Jones, K.E., Price, T., Redding, D.W. \& Owens, I.P. (2012) What is macroecology? Biology Letters, 8, 904-906.

Kerr, J.T. \& Packer, L. (1997) Habitat heterogeneity as a determinant of mammal species richness in highenergy regions. Nature, 385, 252-254. 
Kissling, W.D. \& Carl, G. (2008) Spatial autocorrelation and the selection of simultaneous autoregressive models. Global Ecology and Biogeography, 17, 59-71.

Kreft, H. \& Jetz, W. (2007) Global patterns and determinants of vascular plant diversity. Proceedings of the National Academy of Sciences, USA, 104, 5925-5930.

Legendre, P. (1993) Spatial autocorrelation: trouble or new paradigm? Ecology, 74, 1659-1673.

Lennon, J.J. (2000) Red-shifts and red herrings in geographical ecology. Ecography, 23, 101-113.

Lewin, A., Feldman, A., Bauer, A.M., Belmaker, J., Broadley, D.G., Chirio, L., Itescu, Y., LeBreton, M., Maza, E., Meirte, D., Nagy, Z.T., Novosolov, M., Roll, U., Tallowin, O.J.S., Trape, J-F., Vidan, E. \& Meiri, S. (2016) Patterns of species richness, endemism and environmental gradients of African reptiles. Journal of Biogeography.

Margules, C.R. \& Pressey, R.L. (2000) Systematic conservation planning. Nature, 405, 243-253.

McCain, C.M. (2010) Global analysis of reptile elevational diversity. Global Ecology and Biogeography, 19, 541-553.

McCain, C. M., \& Beck, J. (2016). Species turnover in vertebrate communities along elevational gradients is idiosyncratic and unrelated to species richness. Global Ecology and Biogeography, 25, 299-310.

Moritz, C., Patton, J., Schneider, C. \& Smith, T. (2000) Diversification of rainforest faunas: an integrated molecular approach. Annual Review of Ecology and Systematics, 31, 533-563.

Meiri, S. (2016). Small, rare and trendy: traits and biogeography of lizards described in the 21st century. Journal of Zoology, doi: 10.1111/jzo.12356.

Meiri, S., Bauer, A.M., Chirio, L., Colli, G.R., Das, I., Doan, T.M., Feldman, A., Herrera, F.C., Novosolov, M. \& Pafilis, P. (2013) Are lizards feeling the heat? A tale of ecology and evolution under two temperatures. Global Ecology and Biogeography, 22, 834-845. 
Myers, J.A., Chase, J.M., Jiménez, I., Jørgensen, P.M., Araujo-Murakami, A., Paniagua-Zambrana, N. \& Seidel, R. (2013) Beta-diversity in temperate and tropical forests reflects dissimilar mechanisms of community assembly. Ecology Letters, 16, 151-157.

O'Brien, E.M. (1998) Water-energy dynamics, climate, and prediction of woody plant species richness: an interim general model. Journal of Biogeography, 25, 379-398.

Osorio, F. \& Vallejos, R. (2014). SpatialPack: Package for analysis of spatial data. R package version 0.2-3. Available at: http://cran.r-project.org/package=SpatialPack.

Powney, G.D., Grenyer, R., Orme, C.D.L., Owens, I.P.F. \& Meiri, S. (2010) Hot, dry and different: Australian lizard richness is unlike that of mammals, amphibians and birds. Global Ecology and Biogeography, 19, 386-396.

Pratt, T. K., \& Beehler, B. M. (2014). Birds of New Guinea. Second edition. Princeton University Press, Princeton and Oxford.

Qian, H. (2010) Environment-richness relationships for mammals, birds, reptiles, and amphibians at global and regional scales. Ecological Research, 25, 629-637.

Qian, H. \& Ricklefs, R.E. (2008) Global concordance in diversity patterns of vascular plants and terrestrial vertebrates. Ecology Letters, 11, 547-553.

R Development Core Team (2016) R: a language and environment for statistical computing. R Foundation for Statistical Computing, Vienna, Austria. Available at: http://www.Rproject.org/.

Rahbek, C. \& Graves, G.R. (2001) Multiscale assessment of patterns of avian species richness. Proceedings of the National Academy of Sciences, USA, 98, 4534-4539.

Rahbek, C. (2005) The role of spatial scale and the perception of large-scale species-richness patterns. Ecology letters, 8, 224-239. 
Rahbek, C., Gotelli, N.J., Colwell, R.K., Entsminger, G.L., Rangel, T.F.L. \& Graves, G.R. (2007) Predicting continental-scale patterns of bird species richness with spatially explicit models. Proceedings of the Royal Society of London B: Biological Sciences, 274, 165-174.

Rangel, T.F.L., Diniz-Filho, J.A.F. \& Colwell, R.K. (2007) Species richness and evolutionary niche dynamics: a spatial pattern-oriented simulation experiment. The American Naturalist, 170, 602-616.

Ricklefs, R. E. (2006) Evolutionary diversification and the origin of the diversity-environment relationship. Ecology, 87, 3-13.

Rocchini, D., Hortal, J., Lengyel, S., Lobo, J.M., Jimenez-Valverde, A., Ricotta, C., Bacaro, G. \& Chiarucci, A. (2011) Accounting for uncertainty when mapping species distributions: the need for maps of ignorance. Progress in Physical Geography, 35, 211-226.

Shearman, P. \& Bryan, J. (2010) A bioregional analysis of the distribution of rainforest cover, deforestation and degradation in Papua New Guinea. Austral Ecology, 36, 9-24.

Stein, A., Gerstner, K. \& Kreft, H. (2014) Environmental heterogeneity as a universal driver of species richness across taxa, ecoregions and spatial scales. Ecology Letters, 17, 866-880.

Storch, D. (2012) Biodiversity and its energetic and thermal controls. Metabolic ecology: a scaling approach, 120-131.

Storch, D., Davies, R.G., Zajíček, S., Orme, C.D.L., Olson, V., Thomas, G.H., Ding, T.S., Rasmussen, P.C., Ridgely, R.S. \& Bennett, P.M. (2006) Energy, range dynamics and global species richness patterns: reconciling mid-domain effects and environmental determinants of avian diversity. Ecology Letters, 9, 1308-1320.

Sweet, S.S. \& Pianka, E.R. (2007) Monitors, mammals and Wallace's Line. Mertensiella, 16, 79-99. 
Szabo, N.D., Algar, A.C. \& Kerr, J.T. (2009) Reconciling topographic and climatic effects on widespread and range-restricted species richness. Global Ecology and Biogeography, 18, 735-744.

Tews, J., Brose, U., Grimm, V., Tielbörger, K., Wichmann, M., Schwager, M. \& Jeltsch, F. (2004) Animal species diversity driven by habitat heterogeneity/diversity: the importance of keystone structures. Journal of Biogeography, 31, 79-92.

Thomas, G.H., Orme, C.D.L., Davies, R.G., Olson, V.A., Bennett, P.M., Gaston, K.J., Owens, I.P. \& Blackburn, T.M. (2008) Regional variation in the historical components of global avian species richness. Global Ecology and Biogeography, 17, 340-351.

Toussaint, E.F., Hall, R., Monaghan, M.T., Sagata, K., Ibalim, S., Shaverdo, H.V., Vogler, A.P., Pons, J. \& Balke, M. (2014) The towering orogeny of New Guinea as a trigger for arthropod megadiversity. Nature communications, 5, ncomms5001.

Tuomisto, H., Zuquim, G. \& Cárdenas, G. (2014) Species richness and diversity along edaphic and climatic gradients in Amazonia. Ecography, 37, 1034-1046.

Uetz, P. \& Hošek, J. (2015) The Reptile Database. Available at: http://reptiledatabase.reptarium.cz (Accessed 4 April 2015)

Whittaker, R.J., Willis, K.J. \& Field, R. (2001) Scale and species richness: towards a general, hierarchical theory of species diversity. Journal of Biogeography, 28, 453-470.

Wright, D.H. (1983) Species-energy theory: an extension of species-area theory. Oikos, 41, 496-506.

\section{BIOSKETCH}

Oliver Tallowin is a PhD student at the University of Tel Aviv with a broad interest in understanding biogeographical and macroecological patterns of diversity. His PhD focuses on the ecology and evolution of terrestrial vertebrate diversity in Papua New Guinea.

Author contributions: O.J.S.T. and S.M. conceived the ideas; O.J.S.T. and A.A. compiled and digitised the PNG vertebrate range maps; A.C.A. provided the spreading-dye R script; O.J.S.T. analysed the data and led the writing. 
Editor: Walter Jetz

\section{SUPPORTING INFORMATION}

Appendix S1 - Papua New Guinean vertebrate species list with references.

Appendix S2 - Reptile species distributions at quarter degree grid scale.

Appendix S3 - Species range maps digitized for this study.

Appendix S4 - Gridded Papua New Guinean vertebrate species richness.

Appendix S5 - Papua New Guinea environmental predictors.

Appendix S6 - Morans / correlograms.

Appendix S7 - Richness predictors at half-degree and one-degree resolution.

Appendix S8 - Terrestrial vertebrate species richness in New Guinea. 
Table 1 Cross-taxon congruence in PNG terrestrial vertebrate species richness at the quarter-, half- and onedegree spatial resolution.

\begin{tabular}{|c|c|c|c|c|c|c|}
\hline \multicolumn{7}{|l|}{ Quarter-degree } \\
\hline & Amphibian & Bird & Mammal & Reptile & Lizard & Snake \\
\hline Amphibian & & 0.41 & 0.76 & -0.37 & -0.10 & -0.38 \\
\hline Bird & $0.01(<0.01)$ & & 0.61 & 0.25 & 0.39 & 0.28 \\
\hline Mammal & $<0.01(<0.01)$ & $<0.01(<0.01)$ & & -0.43 & -0.21 & -0.36 \\
\hline Reptile & $0.04(<0.01)$ & $0.07(<0.01)$ & $0.03(<0.01)$ & & 0.88 & 0.93 \\
\hline Lizard & $0.53(0.01)$ & $<0.01(<0.01)$ & $0.22(<0.01)$ & $<0.01(<0.01)$ & & 0.69 \\
\hline Snake & $0.05(<0.01)$ & $0.11(<0.01)$ & $0.10(<0.01)$ & $<0.01(<0.01)$ & $<0.01(<0.01)$ & \\
\hline \multicolumn{7}{|l|}{ Half-degree } \\
\hline Amphibian & & 0.63 & 0.82 & -0.20 & 0.16 & -0.27 \\
\hline Bird & $<0.01(<0.01)$ & & 0.80 & 0.20 & 0.46 & 0.17 \\
\hline Mammal & $<0.01(<0.01)$ & $<0.01(<0.01)$ & & -0.20 & 0.10 & -0.20 \\
\hline Reptile & $0.33(0.01)$ & $0.26(<0.01)$ & $0.36(0.01)$ & & 0.81 & 0.90 \\
\hline Lizard & $0.16(0.04)$ & $0.02(<0.01)$ & $0.60(0.19)$ & $<0.01(<0.01)$ & & 0.54 \\
\hline Snake & $0.26(<0.01)$ & $0.48(0.04)$ & $0.43(0.01)$ & $<0.01(<0.01)$ & $<0.01(<0.01)$ & \\
\hline \multicolumn{7}{|l|}{ One-degree } \\
\hline Amphibian & & 0.68 & 0.85 & 0.04 & 0.45 & -0.19 \\
\hline Bird & $<0.01(<0.01)$ & & 0.87 & 0.44 & 0.68 & 0.23 \\
\hline Mammal & $<0.01(<0.01)$ & $<0.01(<0.01)$ & & 0.18 & 0.47 & $<0.01$ \\
\hline Reptile & $0.85(0.79)$ & $0.09(<0.01)$ & $0.46(0.27)$ & & 0.78 & 0.82 \\
\hline Lizard & $0.04(<0.01)$ & $0.01(<0.01)$ & $0.05(<0.01)$ & $<0.01(<0.01)$ & & 0.36 \\
\hline Snake & $0.52(0.23)$ & $0.47(0.14)$ & $0.97(0.97)$ & $<0.01(<0.01)$ & $0.16(0.02)$ & \\
\hline
\end{tabular}

Cross-taxon congruence using Pearson's $r$ values above the diagonal, with $P$-values, corrected and uncorrected in parenthesis, below the diagonal. Boldface represents significant Pearson's $r$ values, corrected for spatial autocorrelation. Regular font represents significant Pearson's $r$ values, uncorrected for spatial autocorrelation. Grey script represents insignificant Pearson's $r$ values. Degrees of freedom equate to 618 at the quarter-degree, 118 at the half-degree, and 39 at the one-degree spatial resolution. 
Table 2 Ordinary least squares (OLS) regression and simultaneous autoregressive models (SAR) of observed species richness against simulated species richness in the four Papua New Guinea terrestrial vertebrate taxa at the one-degree resolution.

\begin{tabular}{|c|c|c|c|c|c|c|c|c|}
\hline \multirow[b]{2}{*}{ Predictor } & \multicolumn{3}{|l|}{ OLS } & \multicolumn{3}{|c|}{ SAR } & \multirow[b]{2}{*}{$\begin{array}{c}\text { Naglekerke } \\
r^{2}\end{array}$} & \multirow[b]{2}{*}{$\mathrm{AlC}_{\mathrm{c}}$} \\
\hline & Intercept & Slope \pm s.e. & $r^{2}$ & $\mathrm{AlC}_{\mathrm{c}}$ & Intercept & Slope \pm s.e. & & \\
\hline \multicolumn{9}{|l|}{ Amphibian } \\
\hline $\begin{array}{l}\text { Stochastic spreading- } \\
\text { dye }\end{array}$ & 24.877 & $0.855 \pm 0.556$ & 0.03 & 343 & 28.311 & $0.723 \pm 0.572$ & 0.26 & 335 \\
\hline Mean elevation & 28.166 & $0.707 \pm 0.080$ & 0.66 & 301 & 28.742 & $0.687 \pm 0.084$ & 0.69 & 300 \\
\hline Elevational range & 22.565 & $0.967 \pm 0.096$ & 0.72 & 293 & 22.556 & $0.967 \pm 0.093$ & 0.72 & 295 \\
\hline Mid-elevation & 26.531 & $0.781 \pm 0.081$ & 0.69 & 296 & 26.949 & $0.765 \pm 0.084$ & 0.71 & 297 \\
\hline $\begin{array}{l}\text { Net Primary } \\
\text { Productivity }\end{array}$ & 56.204 & $-0.596 \pm 0.247$ & 0.11 & 340 & 52.007 & $-0.479 \pm 0.228$ & 0.31 & 333 \\
\hline $\begin{array}{l}\text { Temperature (mean } \\
\text { annual) }\end{array}$ & 60.804 & $-0.809 \pm 0.095$ & 0.64 & 303 & 59.739 & $-0.794 \pm 0.102$ & 0.67 & 302 \\
\hline $\begin{array}{l}\text { Temperature (annual } \\
\text { range) }\end{array}$ & 22.088 & $0.986 \pm 0.116$ & 0.64 & 303 & 22.476 & $0.973 \pm 0.120$ & 0.65 & 305 \\
\hline $\begin{array}{l}\text { Precipitation (mean } \\
\text { annual) }\end{array}$ & 33.857 & $0.439 \pm 0.208$ & 0.08 & 341 & 34.759 & $0.414 \pm 0.220$ & 0.29 & 334 \\
\hline $\begin{array}{l}\text { Precipitation (annual } \\
\text { range) }\end{array}$ & 22.816 & $0.954 \pm 0.181$ & 0.4 & 324 & 25.593 & $0.837 \pm 0.185$ & 0.47 & 322 \\
\hline \multicolumn{9}{|l|}{ Bird } \\
\hline $\begin{array}{l}\text { Stochastic spreading- } \\
\text { dye }\end{array}$ & 421.717 & $-0.201 \pm 0.193$ & $<0.01$ & 455 & 423.952 & $-0.201 \pm 0.197$ & 0.27 & 445 \\
\hline Mean elevation & 320.574 & $0.303 \pm 0.057$ & 0.41 & 433 & 329.402 & $0.281 \pm 0.061$ & 0.49 & 431 \\
\hline Elevational range & 305.78 & $0.377 \pm 0.061$ & 0.48 & 428 & 309.936 & $0.402 \pm 0.066$ & 0.61 & 420 \\
\hline Mid-elevation & 314.594 & $0.333 \pm 0.057$ & 0.45 & 430 & 322.867 & $0.312 \pm 0.062$ & 0.52 & 428 \\
\hline $\begin{array}{l}\text { Net Primary } \\
\text { Productivity }\end{array}$ & 447.296 & $-0.329 \pm 0.105$ & 0.18 & 447 & 421.091 & $-0.198 \pm 0.103$ & 0.30 & 443 \\
\hline $\begin{array}{l}\text { Temperature (mean } \\
\text { annual) }\end{array}$ & 457.999 & $-0.382 \pm 0.056$ & 0.53 & 424 & 454.04 & $-0.363 \pm 0.058$ & 0.55 & 426 \\
\hline $\begin{array}{l}\text { Temperature (annual } \\
\text { range) }\end{array}$ & 306.742 & $0.372 \pm 0.072$ & 0.39 & 435 & 313.929 & $0.386 \pm 0.078$ & 0.53 & 427 \\
\hline $\begin{array}{l}\text { Precipitation (mean } \\
\text { annual) }\end{array}$ & 390.953 & $-0.048 \pm 0.105$ & $<0.01$ & 456 & 380.57 & $0.040 \pm 0.107$ & 0.25 & 446 \\
\hline $\begin{array}{l}\text { Precipitation (annual } \\
\text { range) }\end{array}$ & 321.577 & $0.298 \pm 0.106$ & 0.15 & 449 & 335.423 & $0.281 \pm 0.101$ & 0.37 & 439 \\
\hline \multicolumn{9}{|l|}{ Mammal } \\
\hline $\begin{array}{l}\text { Stochastic spreading- } \\
\text { dye }\end{array}$ & 70.726 & $0.497 \pm 0.320$ & 0.03 & 388 & 76.037 & $0.422 \pm 0.328$ & 0.28 & 379 \\
\hline Mean elevation & 63.28 & $0.623 \pm 0.065$ & 0.69 & 341 & 63.576 & $0.619 \pm 0.066$ & 0.7 & 343 \\
\hline Elevational range & 55.197 & $0.760 \pm 0.068$ & 0.75 & 332 & 53.995 & $0.786 \pm 0.076$ & 0.78 & 330 \\
\hline Mid-elevation & 60.165 & $0.676 \pm 0.064$ & 0.73 & 335 & 60.067 & $0.677 \pm 0.062$ & 0.74 & 337 \\
\hline $\begin{array}{l}\text { Net Primary } \\
\text { Productivity }\end{array}$ & 113.923 & $-0.237 \pm 0.188$ & 0.01 & 389 & 101.996 & $-0.060 \pm 0.173$ & 0.25 & 381 \\
\hline $\begin{array}{l}\text { Temperature (mean } \\
\text { annual) }\end{array}$ & 134.772 & $-0.591 \pm 0.097$ & 0.48 & 363 & 131.02 & $-0.544 \pm 0.101$ & 0.50 & 364 \\
\hline $\begin{array}{l}\text { Temperature (annual } \\
\text { range) }\end{array}$ & 53.055 & $0.796 \pm 0.080$ & 0.71 & 339 & 52.818 & $0.811 \pm 0.088$ & 0.74 & 337 \\
\hline
\end{tabular}




\begin{tabular}{|c|c|c|c|c|c|c|c|c|}
\hline $\begin{array}{l}\text { Precipitation (mean } \\
\text { annual) }\end{array}$ & 78.686 & $0.362 \pm 0.160$ & 0.09 & 385 & 77.426 & $0.409 \pm 0.163$ & 0.35 & 375 \\
\hline $\begin{array}{l}\text { Precipitation (annual } \\
\text { range) }\end{array}$ & 51.887 & $0.818 \pm 0.134$ & 0.48 & 363 & 57.613 & $0.734 \pm 0.137$ & 0.54 & 361 \\
\hline \multicolumn{9}{|l|}{ Reptile } \\
\hline $\begin{array}{l}\text { Stochastic spreading- } \\
\text { dye }\end{array}$ & 93.482 & $-0.469 \pm 0.196$ & 0.11 & 317 & 88.481 & $-0.345 \pm 0.207$ & 0.22 & 314 \\
\hline Mean elevation & 79.259 & $-0.079 \pm 0.064$ & 0.01 & 321 & 79.567 & $-0.091 \pm 0.067$ & 0.21 & 315 \\
\hline Elevational range & 78.367 & $-0.055 \pm 0.082$ & $<0.01$ & 322 & 77.109 & $-0.020 \pm 0.087$ & 0.17 & 317 \\
\hline Mid-elevation & 77.77 & $-0.038 \pm 0.069$ & $<0.01$ & 322 & 77.681 & $-0.037 \pm 0.072$ & 0.18 & 317 \\
\hline $\begin{array}{l}\text { Net Primary } \\
\text { Productivity }\end{array}$ & 78.374 & $-0.055 \pm 0.118$ & $<0.01$ & 322 & 74.749 & $-0.050 \pm 0.113$ & 0.17 & 317 \\
\hline $\begin{array}{l}\text { Temperature (mean } \\
\text { annual) }\end{array}$ & 76.436 & $-0.002 \pm 0.118$ & $<0.01$ & 323 & 75.612 & $0.023 \pm 0.079$ & 0.17 & 317 \\
\hline $\begin{array}{l}\text { Temperature (annual } \\
\text { range) }\end{array}$ & 79.215 & $-0.078 \pm 0.086$ & $<0.01$ & 322 & 77.913 & $-0.043 \pm 0.092$ & 0.18 & 317 \\
\hline $\begin{array}{l}\text { Precipitation (mean } \\
\text { annual) }\end{array}$ & 82.102 & $-0.157 \pm 0.095$ & 0.04 & 320 & 79.115 & $-0.079 \pm 0.102$ & 0.18 & 316 \\
\hline $\begin{array}{l}\text { Precipitation (annual } \\
\text { range) }\end{array}$ & 74.742 & $0.044 \pm 0.110$ & $<0.01$ & 322 & 73.337 & $0.088 \pm 0.109$ & 0.18 & 316 \\
\hline
\end{tabular}

All models have 39 degrees of freedom. The best model in every set (lowest $\mathrm{AIC}_{\mathrm{c}}$ ) shown in boldface. 


\section{Figure Legends}

Figure 1. Species richness for Papua New Guinea (a) amphibians, (b) birds, (c) mammals, (d) reptiles, (e) lizards and (f) snakes at a quarter-degree resolution using an equal-area Behrmann projection. Note that richness of endotherms and amphibians is correlated with elevation and steep environmental gradients, whereas that of reptiles is confined to the lowlands. Richness is plotted in a 32-quantile spectrum from highest in red to lowest in blue. The legend indicates maximum, median and minimum gridded species richness values.

(a)

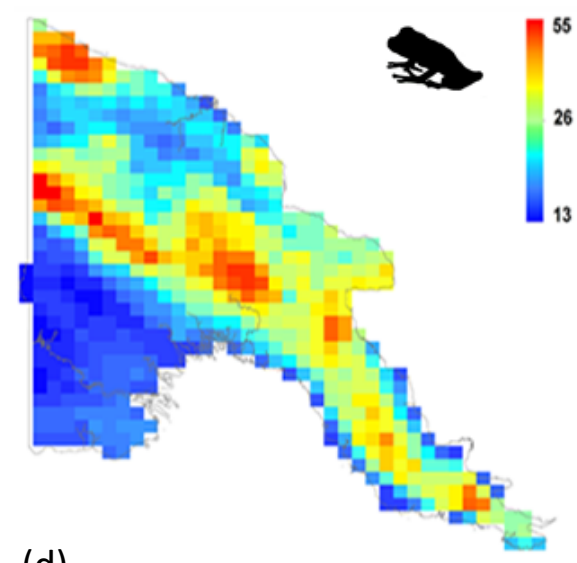

(d)

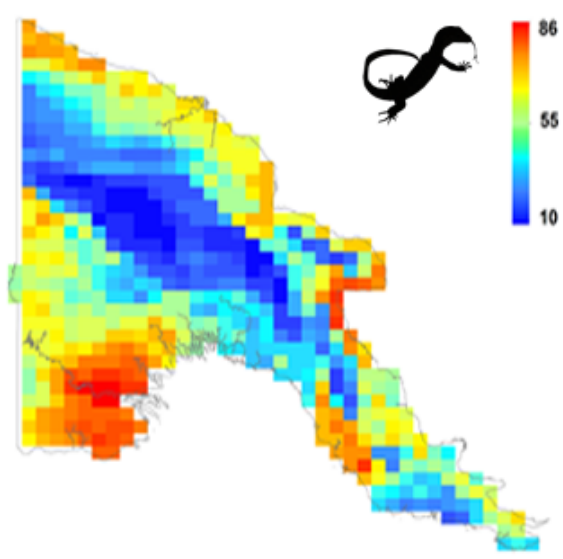

(b)

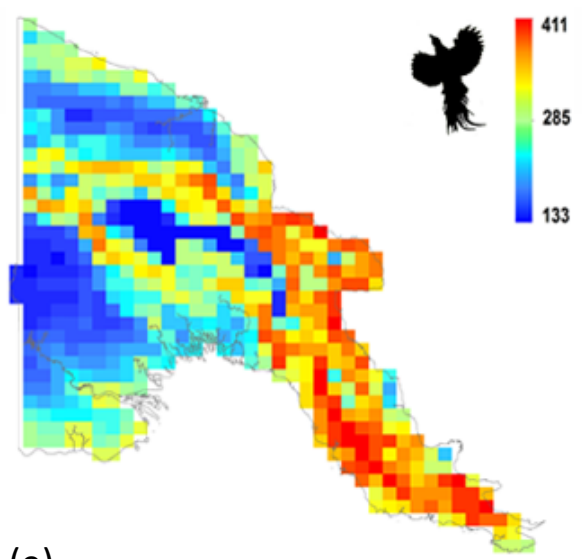

(e)

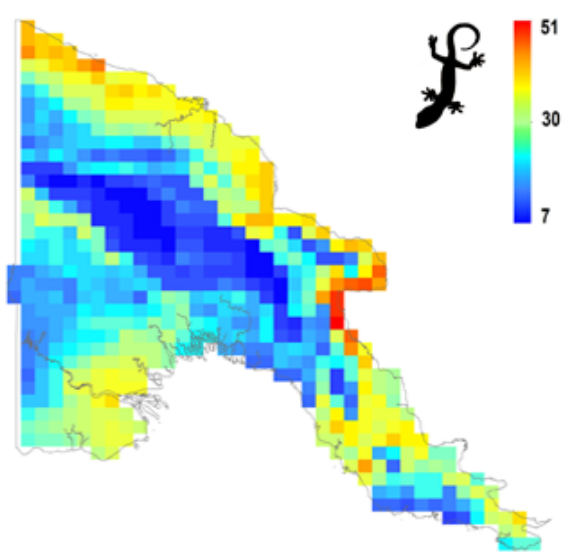

(c)

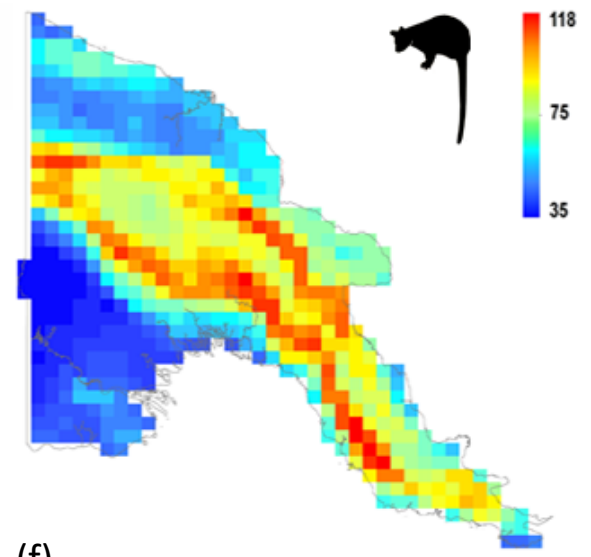

(f)

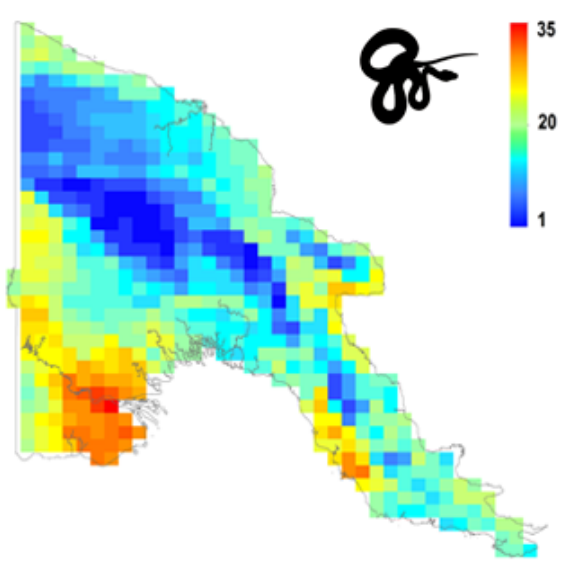


Journal of Biogeography

SUPPORTING INFORMATION

Papua New Guinea terrestrial vertebrate richness: elevation matters most for all except reptiles

Oliver J.S. Tallowin ${ }^{1 *}$, Allen Allison ${ }^{2}$, Adam C. Algar ${ }^{3}$, Fred Kraus ${ }^{4}$ and Shai Meiri ${ }^{1}$

Appendix S1 - Papua New Guinean vertebrate species list with references.

Appendix S2 - Reptile species distributions at quarter degree grid scale.

Appendix S3 - Species range maps digitized for this study.

Appendix S4 - Gridded Papua New Guinean vertebrate species richness.

Appendix S5 - Papua New Guinea environmental predictors.

Appendix S6 - Morans / correlograms.

Appendix S7 - Richness predictors at half-degree and one-degree resolution.

Appendix S8 - Terrestrial vertebrate species richness in New Guinea. 
Appendix S5 - (a) mean elevation ( $m$ ), (b) elevation range (m), (c) mid-elevation peak, (d) net primary productivity $\left(\log _{10}\left(\mathrm{gC}_{\mathrm{yr}}{ }^{-1}\right)\right)$, (e) mean annual precipitation $(\mathrm{mm}),(\mathrm{f})$ mean annual precipitation range $(\mathrm{mm})$, $(\mathrm{g})$ mean annual temperature $\left({ }^{\circ} \mathrm{C}\right)(\mathrm{h})$ mean annual temperature range $\left({ }^{\circ} \mathrm{C}\right)$ at quarter-degree grid resolution using a Behrmann equal-area projection.

(a)

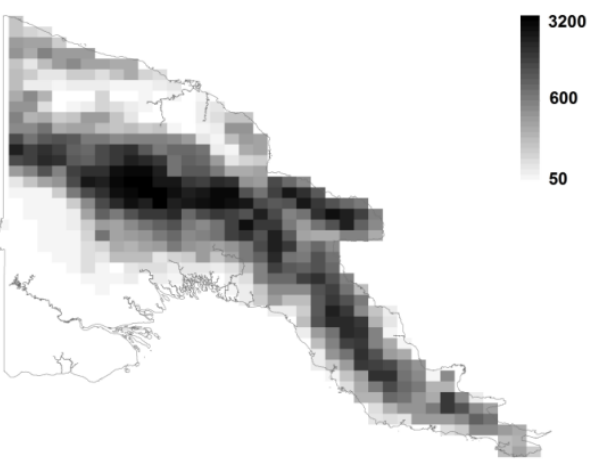

(b)

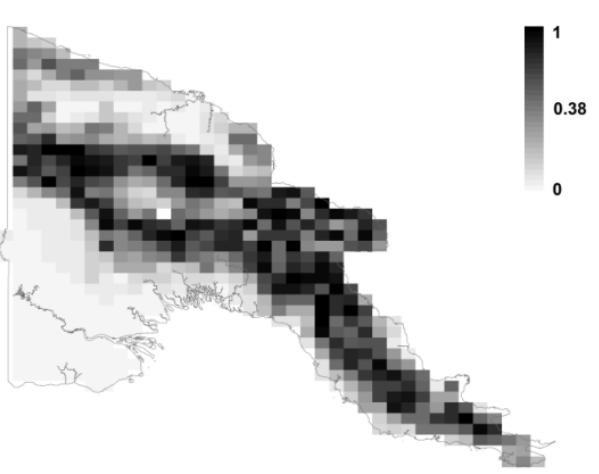

(c)

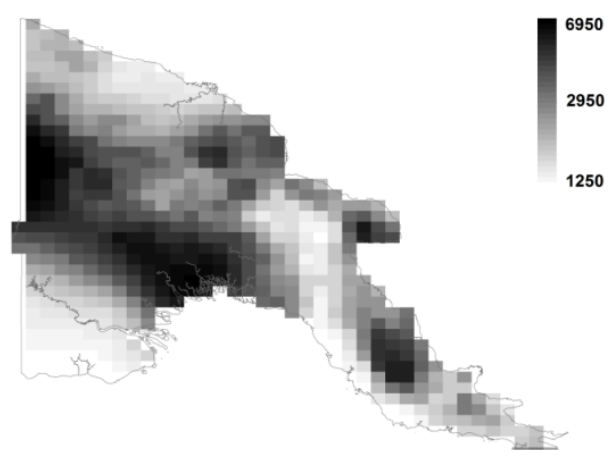

(d)

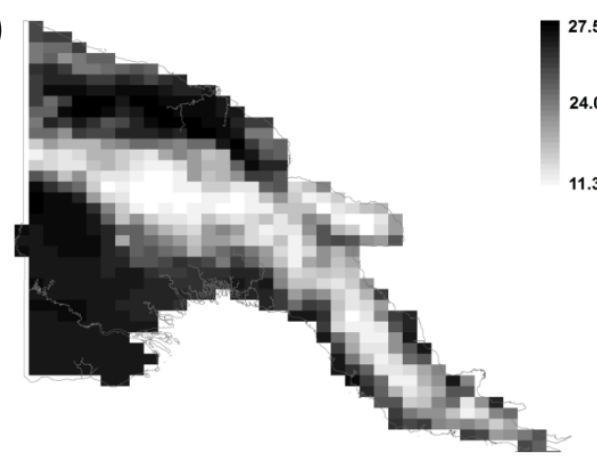

(e)

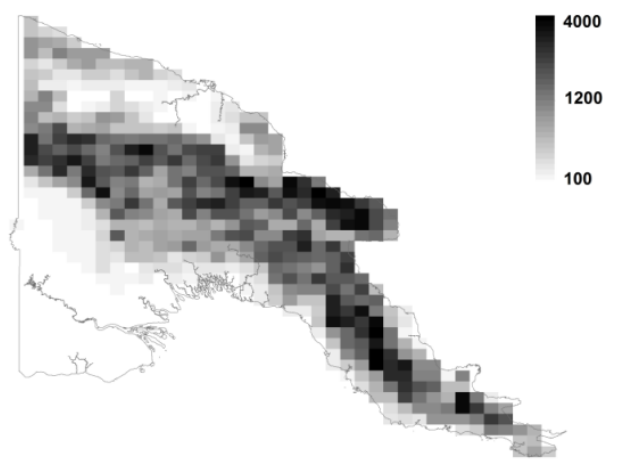

(f)

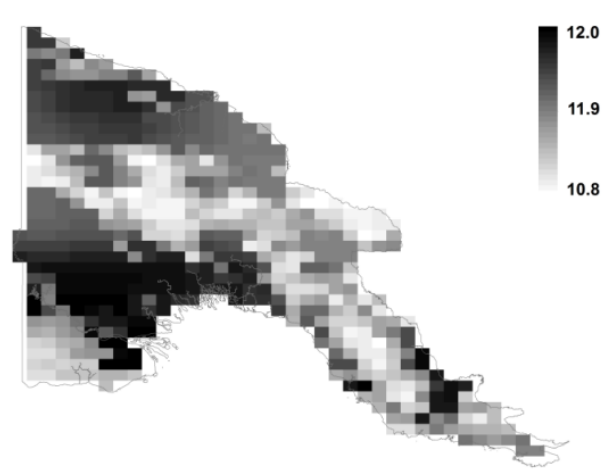

(g)

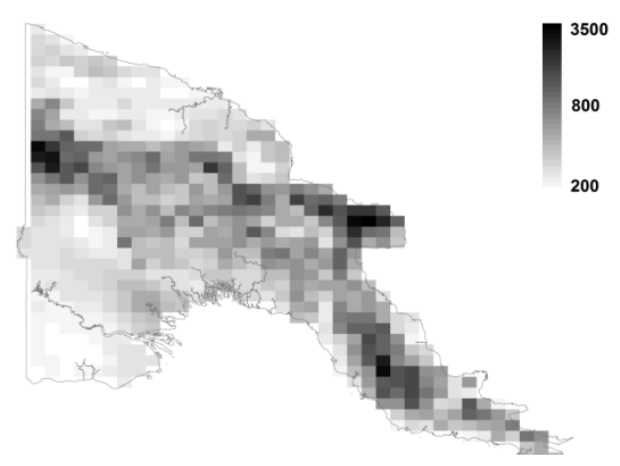

(h)

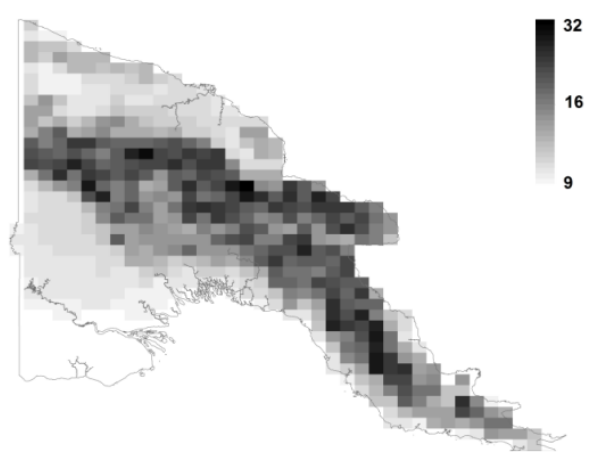


Appendix S6 - Moran's / correlogram showing spatial autocorrelation in PNG (a) amphibian, (b) bird, (c) mammal, (d) reptile, (e) lizard and (f) snake richness and the quarter-, half-, and one-degree spatial resolution. Correlation units on $y$-axis and distance (mean-of-class) on $\mathrm{x}$-axis.

(a)
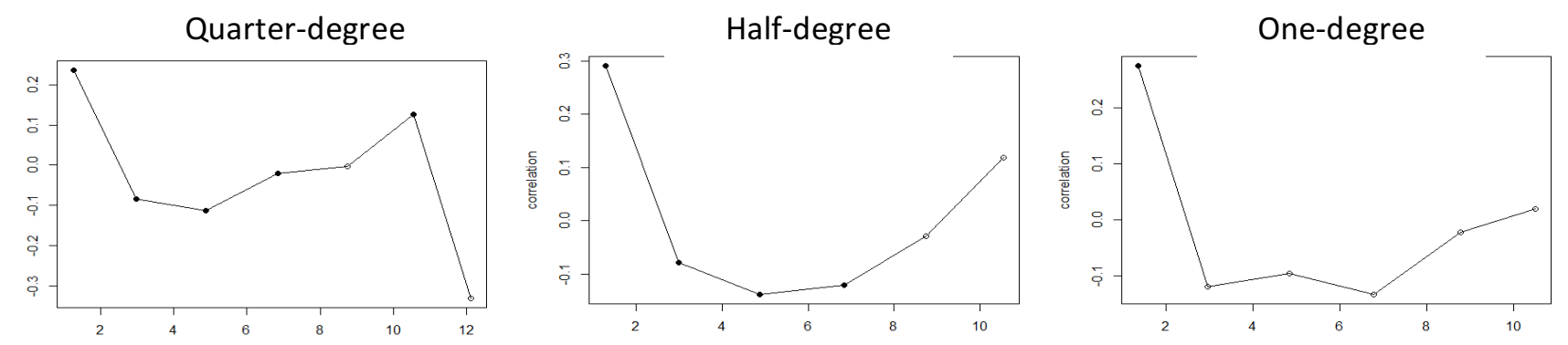

(b)
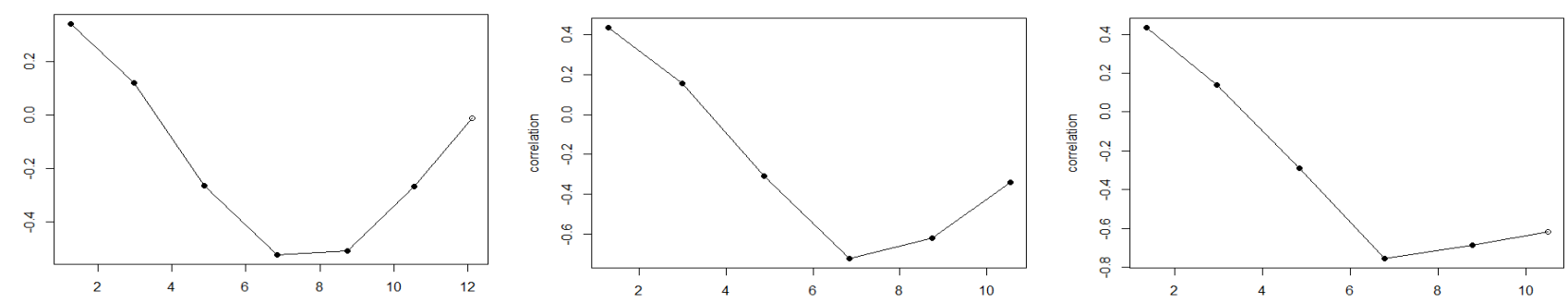

(c)
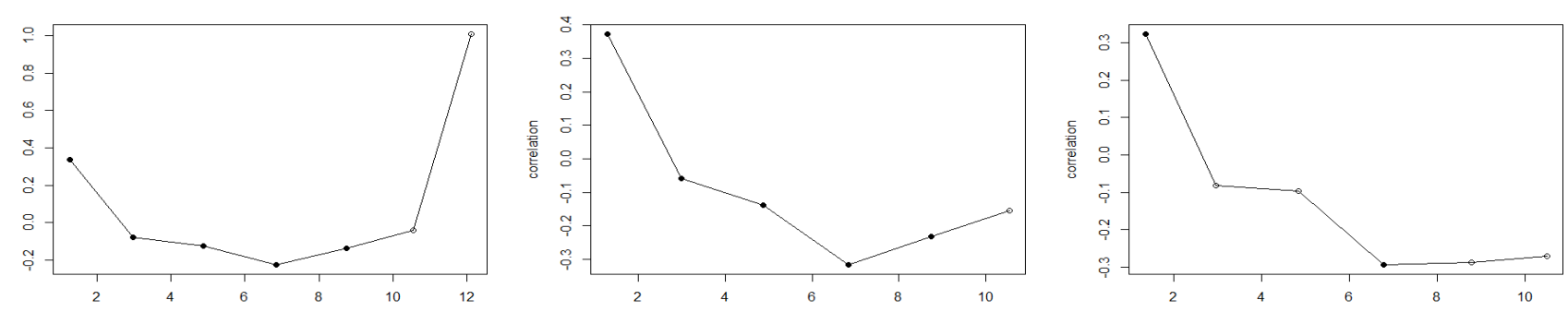

(d)
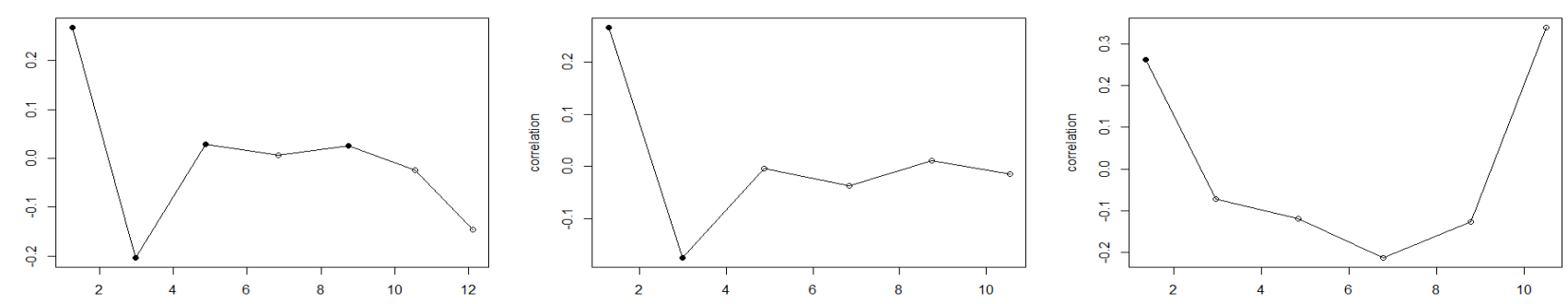

(e)
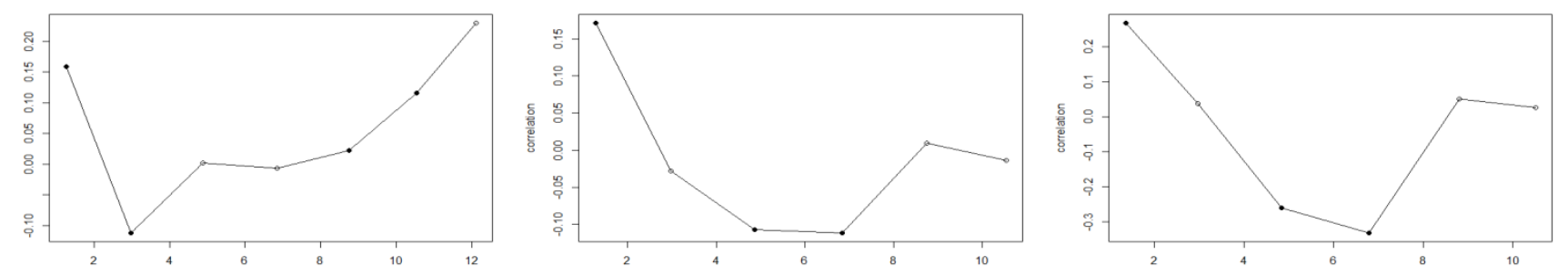
Appendix S7 - Ordinary least squares regression (OLS) and simultaneous autoregressive models (SAR) of observed richness against simulated species richness in six Papua New Guinea terrestrial vertebrate taxa at the (a) quarter-degree, (b) half-degree (c) and lizards and snakes at the one-degree resolution. Models at quarter-, half- and onedegree have 618, 158 and 39 degrees of freedom, respectively. The best model in every set (lowest $\mathrm{AIC}_{\mathrm{c}}$ ) is shown in boldface.

(a) - quarter-degree resolution

\begin{tabular}{|c|c|c|c|c|c|c|c|c|}
\hline & OLS & & & & SAR & & & \\
\hline Predictor & Intercept & Slope \pm s.e. & $r^{2}$ & $\mathrm{AICc}$ & Intercept & Slope \pm s.e. & $\begin{array}{c}\text { Naglekerke } \\
r^{2}\end{array}$ & $\mathrm{AlCc}$ \\
\hline \multicolumn{9}{|l|}{ Amphibian } \\
\hline $\begin{array}{l}\text { Stochastic } \\
\text { spreading-dye }\end{array}$ & 21.57 & $0.25 \pm 0.06$ & 0.03 & 4360 & 14.177 & $0.59 \pm 0.09$ & 0.73 & 3562 \\
\hline Mean elevation & 19.83 & $0.34 \pm 0.01$ & 0.47 & 3978 & 19.031 & $0.36 \pm 0.03$ & 0.79 & 3405 \\
\hline Elevational range & 18.87 & $0.38 \pm 0.02$ & 0.50 & 3946 & 18.622 & $0.38 \pm 0.02$ & 0.80 & 3391 \\
\hline Mid-elevation & 18.46 & $0.40 \pm 0.02$ & 0.50 & 3943 & 18.647 & $0.38 \pm 0.02$ & 0.79 & 3400 \\
\hline $\begin{array}{l}\text { Net Primary } \\
\text { Productivity }\end{array}$ & 32.13 & $-0.28 \pm 0.04$ & 0.06 & 4335 & 24.511 & $0.04 \pm 0.03$ & 0.72 & 3599 \\
\hline $\begin{array}{l}\text { Temperature } \\
\text { (mean annual) }\end{array}$ & 38.82 & $-0.61 \pm 0.04$ & 0.27 & 4177 & 30.300 & $-0.25 \pm 0.06$ & 0.72 & 3587 \\
\hline $\begin{array}{l}\text { Temperature } \\
\text { (annual range) }\end{array}$ & 19.08 & $0.37 \pm 0.04$ & 0.42 & 4038 & 17.796 & $0.43 \pm 0.03$ & 0.80 & 3381 \\
\hline $\begin{array}{l}\text { Precipitation } \\
\text { (mean annual) }\end{array}$ & 23.96 & $0.13 \pm 0.04$ & 0.02 & 4366 & 18.260 & $0.38 \pm 0.07$ & 0.73 & 3569 \\
\hline $\begin{array}{l}\text { Precipitation } \\
\text { (annual range) }\end{array}$ & 17.19 & $0.47 \pm 0.03$ & 0.36 & 4100 & 17.290 & $0.43 \pm 0.04$ & 0.77 & 3466 \\
\hline \multicolumn{9}{|l|}{ Bird } \\
\hline $\begin{array}{l}\text { Stochastic } \\
\text { spreading-dye }\end{array}$ & 344.98 & $-0.25 \pm 0.03$ & 0.10 & 6463 & 336.110 & $-0.21 \pm 0.05$ & 0.58 & 5999 \\
\hline Mean elevation & 261.92 & $0.13 \pm 0.01$ & 0.12 & 6450 & 260.116 & $0.14 \pm 0.02$ & 0.60 & 5970 \\
\hline Elevational range & 252.99 & $0.17 \pm 0.01$ & 0.19 & 6396 & 237.677 & $0.24 \pm 0.03$ & 0.62 & 5932 \\
\hline Mid-elevation & 250.11 & $0.178 \pm 0.01$ & 0.20 & 6388 & 244.613 & $0.22 \pm 0.02$ & 0.63 & 5916 \\
\hline $\begin{array}{l}\text { Net Primary } \\
\text { Productivity }\end{array}$ & 347.06 & $-0.26 \pm 0.02$ & 0.17 & 6414 & 306.513 & $-0.08 \pm 0.03$ & 0.57 & 6007 \\
\hline $\begin{array}{l}\text { Temperature } \\
\text { (mean annual) }\end{array}$ & 343.24 & $-0.24 \pm 0.03$ & 0.12 & 6449 & 275.273 & $0.07 \pm 0.04$ & 0.57 & 6013 \\
\hline $\begin{array}{l}\text { Temperature } \\
\text { (annual range) }\end{array}$ & 263.25 & $0.12 \pm 0.02$ & 0.09 & 6474 & 254.930 & $0.17 \pm 0.02$ & 0.60 & 5965 \\
\hline $\begin{array}{l}\text { Precipitation } \\
\text { (mean annual) }\end{array}$ & 335.67 & $-0.21 \pm 0.02$ & 0.13 & 6446 & 326.823 & $-0.17 \pm 0.04$ & 0.58 & 5997 \\
\hline $\begin{array}{l}\text { Precipitation } \\
\text { (annual range) }\end{array}$ & 265.12 & $0.11 \pm 0.02$ & 0.05 & 6501 & 260.236 & $0.14 \pm 0.03$ & 0.58 & 5994 \\
\hline
\end{tabular}




\begin{tabular}{|c|c|c|c|c|c|c|c|c|}
\hline \multicolumn{9}{|l|}{ Mammal } \\
\hline $\begin{array}{l}\text { Stochastic } \\
\text { spreading-dye }\end{array}$ & 50.69 & $0.39 \pm 0.06$ & 0.07 & 5501 & 33.029 & $0.65 \pm 0.09$ & 0.79 & 4593 \\
\hline Mean elevation & 49.98 & $0.81 \pm 0.02$ & 0.70 & 4803 & 49.164 & $0.82 \pm 0.03$ & 0.86 & 4311 \\
\hline Elevational range & 40.27 & $0.56 \pm 0.01$ & 0.76 & 4673 & 40.780 & $0.55 \pm 0.02$ & 0.88 & 4248 \\
\hline Mid-elevation & 38.30 & $0.59 \pm 0.01$ & 0.77 & 4648 & 40.290 & $0.55 \pm 0.02$ & 0.88 & 4255 \\
\hline $\begin{array}{l}\text { Net Primary } \\
\text { Productivity }\end{array}$ & 85.78 & $-0.16 \pm 0.05$ & 0.02 & 5538 & 66.276 & $0.09 \pm 0.03$ & 0.77 & 4357 \\
\hline $\begin{array}{l}\text { Temperature } \\
\text { (mean annual) }\end{array}$ & 107.51 & $-0.50 \pm 0.05$ & 0.16 & 5441 & 64.583 & $0.11 \pm 0.06$ & 0.77 & 4645 \\
\hline $\begin{array}{l}\text { Temperature } \\
\text { (annual range) } \\
\end{array}$ & 40.45 & $0.56 \pm 0.02$ & 0.66 & 4874 & 38.625 & $0.59 \pm 0.02$ & 0.87 & 4267 \\
\hline $\begin{array}{l}\text { Precipitation } \\
\text { (mean annual) }\end{array}$ & 63.10 & $0.20 \pm 0.04$ & 0.04 & 5527 & 45.305 & $0.45 \pm 0.07$ & 0.78 & 4604 \\
\hline $\begin{array}{l}\text { Precipitation } \\
\text { (annual range) } \\
\end{array}$ & 33.94 & $0.66 \pm 0.02$ & 0.56 & 5046 & 35.886 & $0.62 \pm 0.04$ & 0.84 & 4431 \\
\hline \multicolumn{9}{|l|}{ Reptile } \\
\hline $\begin{array}{l}\text { Stochastic } \\
\text { spreading-dye }\end{array}$ & 78.13 & $-0.62 \pm 0.04$ & 0.24 & 4943 & 74.518 & $-0.54 \pm 0.07$ & 0.69 & 4390 \\
\hline Mean elevation & 65.85 & $-0.33 \pm 0.01$ & 0.48 & 4715 & 63.287 & $-0.27 \pm 0.02$ & 0.71 & 4351 \\
\hline Elevational range & 65.84 & $-0.26 \pm 0.01$ & 0.35 & 4848 & 59.115 & $-0.12 \pm 0.02$ & 0.68 & 4417 \\
\hline Mid-elevation & 65.08 & $-0.31 \pm 0.02$ & 0.32 & 4879 & 55.359 & $-0.05 \pm 0.03$ & 0.67 & 4432 \\
\hline $\begin{array}{l}\text { Net Primary } \\
\text { Productivity }\end{array}$ & 53.51 & $-0.02 \pm 0.04$ & $<0.01$ & 5117 & 52.711 & $0.03 \pm 0.04$ & 0.67 & 4433 \\
\hline $\begin{array}{l}\text { Temperature } \\
\text { (mean annual) }\end{array}$ & 38.65 & $0.36 \pm 0.04$ & 0.11 & 5045 & 32.704 & $0.56 \pm 0.06$ & 0.71 & 4353 \\
\hline $\begin{array}{l}\text { Temperature } \\
\text { (annual range) }\end{array}$ & 66.76 & $-0.36 \pm 0.02$ & 0.40 & 4798 & 60.751 & $-0.20 \pm 0.03$ & 0.68 & 4409 \\
\hline $\begin{array}{l}\text { Precipitation } \\
\text { (mean annual) }\end{array}$ & 68.03 & $-0.39 \pm 0.03$ & 0.18 & 4991 & 66.979 & $-0.36 \pm 0.06$ & 0.69 & 4397 \\
\hline $\begin{array}{l}\text { Precipitation } \\
\text { (annual range) }\end{array}$ & 70.54 & $-0.45 \pm 0.02$ & 0.36 & 4835 & 64.856 & $-0.31 \pm 0.04$ & 0.69 & 4387 \\
\hline \multicolumn{9}{|l|}{ Lizard } \\
\hline $\begin{array}{l}\text { Stochastic } \\
\text { spreading-dye }\end{array}$ & 44.876 & $-0.690 \pm 0.046$ & 0.27 & 4172 & 42.737 & $-0.601 \pm 0.075$ & 0.62 & 3771 \\
\hline Mean elevation & 34.603 & $-0.218 \pm 0.016$ & 0.24 & 4200 & 33.383 & $-0.163 \pm 0.025$ & 0.61 & 3789 \\
\hline Elevational range & 33.713 & $-0.178 \pm 0.019$ & 0.13 & 4282 & 30.723 & $-0.034 \pm 0.029$ & 0.59 & 3821 \\
\hline Mid-elevation & 33.741 & $-0.179 \pm 0.020$ & 0.12 & 4289 & 29.336 & $0.036 \pm 0.030$ & 0.59 & 3822 \\
\hline $\begin{array}{l}\text { Net Primary } \\
\text { Productivity }\end{array}$ & 33.214 & $-0.155 \pm 0.039$ & 0.02 & 4352 & 30.469 & $-0.021 \pm 0.039$ & 0.59 & 3822 \\
\hline $\begin{array}{l}\text { Temperature } \\
\text { (mean annual) }\end{array}$ & 27.778 & $0.095 \pm 0.043$ & 0.01 & 4363 & 22.687 & $0.348 \pm 0.064$ & 0.60 & 3795 \\
\hline $\begin{array}{l}\text { Temperature } \\
\text { (annual range) }\end{array}$ & 34.754 & $-0.226 \pm 0.019$ & 0.18 & 4241 & 31.769 & $-0.086 \pm 0.031$ & 0.59 & 3817 \\
\hline $\begin{array}{l}\text { Precipitation } \\
\text { (mean annual) }\end{array}$ & 38.658 & $-0.405 \pm 0.031$ & 0.22 & 4216 & 37.654 & $-0.364 \pm 0.053$ & 0.61 & 3782 \\
\hline
\end{tabular}




\begin{tabular}{|c|c|c|c|c|c|c|c|c|}
\hline $\begin{array}{l}\text { Precipitation } \\
\text { (annual range) }\end{array}$ & 36.634 & $-0.312 \pm 0.026$ & 0.19 & 4235 & 34.183 & $-0.200 \pm 0.039$ & 0.60 & 3801 \\
\hline \multicolumn{9}{|l|}{ Snake } \\
\hline $\begin{array}{l}\text { Stochastic } \\
\text { spreading-dye }\end{array}$ & 28.990 & $-0.609 \pm 0.054$ & 0.17 & 3935 & 28.396 & $-0.570 \pm 0.089$ & 0.70 & 3303 \\
\hline Mean elevation & 25.547 & $-0.379 \pm 0.019$ & 0.39 & 3745 & 24.181 & $-0.283 \pm 0.030$ & 0.71 & 3278 \\
\hline Elevational range & 25.140 & $-0.351 \pm 0.022$ & 0.29 & 3835 & 22.576 & $-0.166 \pm 0.033$ & 0.69 & 3321 \\
\hline Mid-elevation & 25.147 & $-0.352 \pm 0.023$ & 0.27 & 3860 & 21.505 & $-0.087 \pm 0.035$ & 0.69 & 3335 \\
\hline $\begin{array}{l}\text { Net Primary } \\
\text { Productivity }\end{array}$ & 20.044 & $-0.009 \pm 0.047$ & 0.01 & 4053 & 20.130 & $0.018 \pm 0.040$ & 0.68 & 3339 \\
\hline $\begin{array}{l}\text { Temperature } \\
\text { (mean annual) }\end{array}$ & 13.790 & $0.409 \pm 0.049$ & 0.10 & 3986 & 11.865 & $0.588 \pm 0.066$ & 0.72 & 3265 \\
\hline $\begin{array}{l}\text { Temperature } \\
\text { (annual range) }\end{array}$ & 25.969 & $-0.407 \pm 0.023$ & 0.35 & 3790 & 23.444 & $-0.232 \pm 0.035$ & 0.70 & 3311 \\
\hline $\begin{array}{l}\text { Precipitation } \\
\text { (mean annual) }\end{array}$ & 25.838 & $-0.398 \pm 0.040$ & 0.14 & 3959 & 25.292 & $-0.354 \pm 0.067$ & 0.70 & 3314 \\
\hline $\begin{array}{l}\text { Precipitation } \\
\text { (annual range) }\end{array}$ & 27.066 & $-0.480 \pm 0.031$ & 0.28 & 3848 & 24.798 & $-0.322 \pm 0.047$ & 0.70 & 3303 \\
\hline
\end{tabular}

(b) - half-degree resolution

\begin{tabular}{|c|c|c|c|c|c|c|c|c|}
\hline \multirow[b]{2}{*}{ Predictor } & \multicolumn{4}{|l|}{ OLS } & \multicolumn{2}{|l|}{ SAR } & \multirow[b]{2}{*}{$\begin{array}{c}\text { Naglekerke } \\
r^{2}\end{array}$} & \multirow[b]{2}{*}{$\mathrm{AlC}_{\mathrm{c}}$} \\
\hline & Intercept & Slope \pm s.e. & $r^{2}$ & $\mathrm{AlC}_{\mathrm{c}}$ & Intercept & Slope \pm s.e. & & \\
\hline \multicolumn{9}{|l|}{ Amphibian } \\
\hline $\begin{array}{l}\text { Stochastic } \\
\text { spreading-dye }\end{array}$ & 25.32 & $0.337 \pm 0.171$ & 0.02 & 1212 & 23.356 & $0.426 \pm 0.204$ & 0.51 & 1105 \\
\hline Mean elevation & 23.272 & $0.439 \pm 0.171$ & 0.53 & 1092 & 23.446 & $0.434 \pm 0.040$ & 0.70 & 1027 \\
\hline Elevational range & 20.262 & $0.591 \pm 0.037$ & 0.62 & 1062 & 20.284 & $0.599 \pm 0.048$ & 0.73 & 1009 \\
\hline Mid-elevation & 22.15 & $0.496 \pm 0.034$ & 0.58 & 1077 & 22.74 & $0.474 \pm 0.041$ & 0.71 & 1019 \\
\hline $\begin{array}{l}\text { Net Primary } \\
\text { Productivity }\end{array}$ & 43.579 & $-0.581 \pm 0.104$ & 0.16 & 1187 & 37.249 & $-0.347 \pm 0.096$ & 0.53 & 1097 \\
\hline $\begin{array}{l}\text { Temperature } \\
\text { (mean annual) }\end{array}$ & 50.415 & $-0.923 \pm 0.078$ & 0.47 & 1114 & 47.042 & $-0.815 \pm 0.100$ & 0.63 & 1061 \\
\hline $\begin{array}{l}\text { Temperature } \\
\text { (annual range) }\end{array}$ & 20.295 & $0.589 \pm 0.043$ & 0.54 & 1090 & 20.35 & $0.608 \pm 0.056$ & 0.70 & 1025 \\
\hline $\begin{array}{l}\text { Precipitation } \\
\text { (mean annual) }\end{array}$ & 28.404 & $0.182 \pm 0.075$ & 0.03 & 1210 & 26.972 & $0.233 \pm 0.102$ & 0.51 & 1104 \\
\hline $\begin{array}{l}\text { Precipitation } \\
\text { (annual range) }\end{array}$ & 19.38 & $0.634 \pm 0.058$ & 0.42 & 1128 & 21.109 & $0.554 \pm 0.073$ & 0.62 & 1063 \\
\hline \multicolumn{9}{|l|}{ Bird } \\
\hline $\begin{array}{l}\text { Stochastic } \\
\text { spreading-dye }\end{array}$ & 386.444 & $-0.278 \pm 0.074$ & 0.08 & 1719 & 369.826 & $-0.209 \pm 0.092$ & 0.53 & 1615 \\
\hline Mean elevation & 279.782 & $0.220 \pm 0.027$ & 0.29 & 1677 & 288.735 & $0.203 \pm 0.033$ & 0.60 & 1587 \\
\hline Elevational range & 266.446 & $0.282 \pm 0.028$ & 0.39 & 1654 & 271.42 & $0.286 \pm 0.036$ & 0.65 & 1567 \\
\hline Mid-elevation & 272.755 & $0.253 \pm 0.027$ & 0.35 & 1663 & 280.879 & $0.244 \pm 0.033$ & 0.64 & 1573 \\
\hline $\begin{array}{l}\text { Net Primary } \\
\text { Productivity }\end{array}$ & 411.161 & $-0.394 \pm 0.051$ & 0.27 & 1682 & 361.287 & $-0.165 \pm 0.051$ & 0.54 & 1611 \\
\hline
\end{tabular}




\begin{tabular}{|c|c|c|c|c|c|c|c|c|}
\hline $\begin{array}{l}\text { Temperature } \\
\text { (mean annual) }\end{array}$ & 427.196 & $-0.469 \pm 0.045$ & 0.40 & 1650 & 384.683 & $-0.274 \pm 0.058$ & 0.55 & 1607 \\
\hline $\begin{array}{l}\text { Temperature } \\
\text { (annual range) }\end{array}$ & 272.992 & $0.251 \pm 0.033$ & 0.27 & 1683 & 280.696 & $0.248 \pm 0.042$ & 0.60 & 1589 \\
\hline $\begin{array}{l}\text { Precipitation } \\
\text { (mean annual) }\end{array}$ & 353.467 & $-0.124 \pm 0.044$ & 0.04 & 1725 & 340.04 & $-0.058 \pm 0.056$ & 0.52 & 1619 \\
\hline $\begin{array}{l}\text { Precipitation } \\
\text { (annual range) }\end{array}$ & 273.896 & $0.247 \pm 0.041$ & 0.18 & 1700 & 291.896 & $0.187 \pm 0.049$ & 0.55 & 1607 \\
\hline \multicolumn{9}{|l|}{ Mammal } \\
\hline $\begin{array}{l}\text { Stochastic } \\
\text { spreading-dye }\end{array}$ & 65.266 & $0.317 \pm 0.134$ & 0.03 & 1475 & 66.049 & $0.300 \pm 0.157$ & 0.58 & 1343 \\
\hline Mean elevation & 51.263 & $0.546 \pm 0.030$ & 0.68 & 1299 & 54.133 & $0.510 \pm 0.038$ & 0.78 & 1242 \\
\hline Elevational range & 44.29 & $0.660 \pm 0.031$ & 0.74 & 1263 & 45.095 & $0.661 \pm 0.041$ & 0.82 & 1206 \\
\hline Mid-elevation & 48.025 & $0.600 \pm 0.030$ & 0.73 & 1269 & 50.658 & $0.570 \pm 0.036$ & 0.81 & 1215 \\
\hline $\begin{array}{l}\text { Net Primary } \\
\text { Productivity }\end{array}$ & 107.039 & $-0.366 \pm 0.100$ & 0.07 & 1468 & 83.296 & $-0.022 \pm 0.080$ & 0.57 & 1347 \\
\hline $\begin{array}{l}\text { Temperature } \\
\text { (mean annual) }\end{array}$ & 128.461 & $-0.717 \pm 0.084$ & 0.31 & 1420 & 102.48 & $-0.346 \pm 0.098$ & 0.60 & 1337 \\
\hline $\begin{array}{l}\text { Temperature } \\
\text { (annual range) } \\
\end{array}$ & 44.727 & $0.653 \pm 0.037$ & 0.66 & 1308 & 46.282 & $0.651 \pm 0.050$ & 0.78 & 1241 \\
\hline $\begin{array}{l}\text { Precipitation } \\
\text { (mean annual) }\end{array}$ & 74.183 & $0.275 \pm 0.093$ & 0.05 & 1472 & 71.192 & $0.347 \pm 0.122$ & 0.59 & 1339 \\
\hline $\begin{array}{l}\text { Precipitation } \\
\text { (annual range) }\end{array}$ & 41.595 & $0.704 \pm 0.052$ & 0.53 & 1358 & 48.916 & $0.595 \pm 0.066$ & 0.70 & 1293 \\
\hline
\end{tabular}

\begin{tabular}{|c|c|c|c|c|c|c|c|c|}
\hline Reptile & & & & & & & & \\
\hline $\begin{array}{l}\text { Stochastic } \\
\text { spreading-dye }\end{array}$ & 83.22 & $-0.570 \pm 0.092$ & 0.19 & 1247 & 78.532 & $-0.461 \pm 0.120$ & 0.48 & 1180 \\
\hline Mean elevation & 69.63 & $-0.212 \pm 0.028$ & 0.25 & 1234 & 67.906 & $-0.167 \pm 0.036$ & 0.49 & 1176 \\
\hline Elevational range & 69.482 & $-0.208 \pm 0.037$ & 0.16 & 1252 & 65.617 & $-0.100 \pm 0.048$ & 0.44 & 1190 \\
\hline Mid-elevation & 68.557 & $-0.184 \pm 0.032$ & 0.16 & 1252 & 65.785 & $-0.107 \pm 0.040$ & 0.45 & 1187 \\
\hline $\begin{array}{l}\text { Net Primary } \\
\text { Productivity }\end{array}$ & 63.493 & $-0.051 \pm 0.074$ & $<0.01$ & 1281 & 65.358 & $-0.089 \pm 0.069$ & 0.44 & 1191 \\
\hline $\begin{array}{l}\text { Temperature } \\
\text { (mean annual) }\end{array}$ & 53.968 & $0.199 \pm 0.069$ & 0.04 & 1273 & 55.406 & $0.189 \pm 0.084$ & 0.45 & 1188 \\
\hline $\begin{array}{l}\text { Temperature } \\
\text { (annual range) }\end{array}$ & 70.825 & $-0.244 \pm 0.038$ & 0.20 & 1244 & 67.355 & $-0.152 \pm 0.050$ & 0.46 & 1186 \\
\hline $\begin{array}{l}\text { Precipitation } \\
\text { (mean annual) }\end{array}$ & 70.523 & $-0.235 \pm 0.047$ & 0.13 & 1258 & 68.402 & $-0.181 \pm 0.066$ & 0.46 & 1186 \\
\hline $\begin{array}{c}\text { Precipitation } \\
\text { (annual range) }\end{array}$ & 70.214 & $-0.228 \pm 0.049$ & 0.12 & 1261 & 66.992 & $-0.139 \pm 0.060$ & 0.449 & 1188 \\
\hline \multicolumn{9}{|l|}{ Lizard } \\
\hline $\begin{array}{l}\text { Stochastic } \\
\text { spreading-dye }\end{array}$ & 46.588 & $-0.547 \pm 0.103$ & 0.15 & 1090 & 43.847 & $-0.435 \pm 0.132$ & 0.41 & 1033 \\
\hline Mean elevation & 36.771 & $-0.084 \pm 0.033$ & 0.03 & 1110 & 36.071 & $-0.049 \pm 0.041$ & 0.38 & 1041 \\
\hline Elevational range & 35.326 & $-0.016 \pm 0.042$ & 0.01 & 1116 & 33.681 & $0.076 \pm 0.054$ & 0.38 & 1041 \\
\hline Mid-elevation & 35.840 & $-0.040 \pm 0.037$ & 0.01 & 1115 & 34.674 & $0.024 \pm 0.044$ & 0.38 & 1042 \\
\hline $\begin{array}{l}\text { Net Primary } \\
\text { Productivity }\end{array}$ & 39.325 & $-0.205 \pm 0.077$ & 0.04 & 1109 & 38.296 & $-0.161 \pm 0.076$ & 0.39 & 1038 \\
\hline
\end{tabular}




\begin{tabular}{|c|c|c|c|c|c|c|c|c|}
\hline $\begin{array}{l}\text { Temperature } \\
\text { (mean annual) }\end{array}$ & 37.130 & $-0.101 \pm 0.073$ & 0.01 & 1114 & 35.485 & $-0.017 \pm 0.091$ & 0.38 & 1042 \\
\hline $\begin{array}{l}\text { Temperature } \\
\text { (annual range) }\end{array}$ & 36.203 & $-0.057 \pm 0.044$ & 0.01 & 1115 & 34.510 & $-0.033 \pm 0.058$ & 0.38 & 1042 \\
\hline $\begin{array}{l}\text { Precipitation } \\
\text { (mean annual) }\end{array}$ & 39.909 & $-0.232 \pm 0.050$ & 0.11 & 1096 & 38.584 & $-0.176 \pm 0.069$ & 0.40 & 1037 \\
\hline $\begin{array}{l}\text { Precipitation } \\
\text { (annual range) }\end{array}$ & 36.382 & $-0.066 \pm 0.054$ & 0.01 & 1115 & 35.287 & $-0.008 \pm 0.066$ & 0.38 & 1042 \\
\hline \multicolumn{9}{|l|}{ Snake } \\
\hline $\begin{array}{l}\text { Stochastic } \\
\text { spreading-dye }\end{array}$ & 30.982 & $-0.579 \pm 0.107$ & 0.15 & 987 & 30.550 & $-0.548 \pm 0.135$ & 0.53 & 895 \\
\hline Mean elevation & 26.320 & $-0.256 \pm 0.038$ & 0.22 & 973 & 25.756 & $-0.196 \pm 0.046$ & 0.53 & 895 \\
\hline Elevational range & 26.721 & $-0.284 \pm 0.044$ & 0.20 & 977 & 25.452 & $-0.172 \pm 0.057$ & 0.51 & 903 \\
\hline Mid-elevation & 25.965 & $-0.231 \pm 0.041$ & 0.16 & 985 & 25.011 & $-0.138 \pm 0.050$ & 0.51 & 904 \\
\hline $\begin{array}{l}\text { Net Primary } \\
\text { Productivity }\end{array}$ & 23.252 & $-0.044 \pm 0.087$ & 0.01 & 1014 & 24.436 & $-0.081 \pm 0.079$ & 0.49 & 909 \\
\hline $\begin{array}{l}\text { Temperature } \\
\text { (mean annual) }\end{array}$ & 19.374 & $-0.224 \pm 0.082$ & 0.04 & 1007 & 20.842 & $0.184 \pm 0.096$ & 0.50 & 906 \\
\hline $\begin{array}{l}\text { Temperature } \\
\text { (annual range) }\end{array}$ & 27.216 & $-0.318 \pm 0.047$ & 0.22 & 973 & 26.154 & $-0.228 \pm 0.060$ & 0.52 & 899 \\
\hline $\begin{array}{l}\text { Precipitation } \\
\text { (mean annual) }\end{array}$ & 26.784 & $-0.288 \pm 0.058$ & 0.13 & 991 & 26.443 & $-0.247 \pm 0.078$ & 0.51 & 901 \\
\hline $\begin{array}{l}\text { Precipitation } \\
\text { (annual range) }\end{array}$ & 26.462 & $-0.266 \pm 0.060$ & 0.11 & 995 & 25.734 & $-0.188 \pm 0.072$ & 0.51 & 904 \\
\hline
\end{tabular}

(c) - one-degree resolution

\begin{tabular}{|c|c|c|c|c|c|c|c|c|}
\hline \multirow[b]{2}{*}{ Predictor } & \multicolumn{4}{|l|}{ OLS } & \multicolumn{4}{|l|}{ SAR } \\
\hline & Intercept & Slope \pm s.e. & $r^{2}$ & $\mathrm{AlC}_{\mathrm{c}}$ & Intercept & Slope \pm s.e. & $\begin{array}{c}\text { Naglekerke } \\
r^{2}\end{array}$ & $\mathrm{AlC}_{\mathrm{C}}$ \\
\hline \multicolumn{9}{|l|}{ Lizard } \\
\hline $\begin{array}{l}\text { Stochastic } \\
\text { spreading-dye }\end{array}$ & 50.857 & $-0.319 \pm 0.251$ & 0.02 & 289 & 47.782 & $-0.178 \pm 0.263$ & 0.22 & 283 \\
\hline Mean elevation & 42.760 & $0.077 \pm 0.075$ & 0.01 & 290 & 43.770 & $0.030 \pm 0.077$ & 0.21 & 283 \\
\hline Elevational range & 40.204 & $0.202 \pm 0.092$ & 0.09 & 286 & 40.486 & $0.197 \pm 0.097$ & 0.28 & 279 \\
\hline Mid-elevation & 41.526 & $0.138 \pm 0.078$ & 0.05 & 288 & 42.254 & $0.108 \pm 0.080$ & 0.24 & 282 \\
\hline $\begin{array}{l}\text { Net Primary } \\
\text { Productivity }\end{array}$ & 48.882 & $-0.221 \pm 0.135$ & 0.04 & 288 & 45.044 & $-0.037 \pm 0.130$ & 0.21 & 283 \\
\hline $\begin{array}{l}\text { Temperature } \\
\text { (mean annual) }\end{array}$ & 48.804 & $-0.217 \pm 0.082$ & 0.13 & 284 & 47.583 & $-0.166 \pm 0.086$ & 0.27 & 280 \\
\hline $\begin{array}{l}\text { Temperature } \\
\text { (annual range) }\end{array}$ & 40.703 & $0.178 \pm 0.100$ & 0.05 & 288 & 40.900 & $0.179 \pm 0.106$ & 0.26 & 280 \\
\hline $\begin{array}{l}\text { Precipitation } \\
\text { (mean annual) }\end{array}$ & 46.509 & $-0.106 \pm 0.115$ & 0.01 & 290 & 44.374 & $0.513 \pm 0.122$ & 0.21 & 283 \\
\hline $\begin{array}{l}\text { Precipitation } \\
\text { (annual range) }\end{array}$ & 39.858 & $0.219 \pm 0.127$ & 0.05 & 288 & 39.634 & $0.244 \pm 0.124$ & 0.28 & 280 \\
\hline \multicolumn{9}{|l|}{ Snake } \\
\hline $\begin{array}{l}\text { Stochastic } \\
\text { spreading-dye }\end{array}$ & 36.372 & $-0.690 \pm 0.233$ & 0.16 & 250 & 34.730 & $-0.599 \pm 0.228$ & 0.49 & 233 \\
\hline
\end{tabular}




\begin{tabular}{|c|c|c|c|c|c|c|c|c|}
\hline Mean elevation & 29.160 & $-0.163 \pm 0.083$ & 0.07 & 255 & 29.365 & $-0.141 \pm 0.077$ & 0.45 & 236 \\
\hline Elevational range & 30.079 & $-0.230 \pm 0.099$ & 0.10 & 253 & 29.300 & $-0.137 \pm 0.097$ & 0.43 & 237 \\
\hline Mid-elevation & 28.732 & $-0.132 \pm 0.089$ & 0.03 & 256 & 28.799 & $-0.095 \pm 0.083$ & 0.43 & 238 \\
\hline $\begin{array}{l}\text { Net Primary } \\
\text { Productivity }\end{array}$ & 27.846 & $-0.067 \pm 0.147$ & 0.01 & 258 & 27.601 & $-0.003 \pm 0.119$ & 0.41 & 239 \\
\hline $\begin{array}{l}\text { Temperature } \\
\text { (mean annual) }\end{array}$ & 26.364 & $0.041 \pm 0.099$ & 0.01 & 258 & 27.122 & $-0.046 \pm 0.088$ & 0.41 & 239 \\
\hline $\begin{array}{l}\text { Temperature } \\
\text { (annual range) }\end{array}$ & 30.443 & $-0.256 \pm 0.105$ & 0.11 & 253 & 29.755 & $-0.177 \pm 0.104$ & 0.44 & 236 \\
\hline $\begin{array}{l}\text { Precipitation } \\
\text { (mean annual) }\end{array}$ & 30.999 & $-0.298 \pm 0.117$ & 0.12 & 252 & 29.745 & $-0.191 \pm 0.116$ & 0.44 & 237 \\
\hline $\begin{array}{l}\text { Precipitation } \\
\text { (annual range) }\end{array}$ & 28.350 & $-0.105 \pm 0.143$ & 0.01 & 258 & 28.226 & $-0.050 \pm 0.121$ & 0.41 & 239 \\
\hline
\end{tabular}


Appendix 58 - The geographic distribution of (a) amphibian (b) bird (c) mammal (d) reptile (e) lizard and (f) snake species richness in New Guinea (as opposed to PNG, Fig. 1) at a quarter-degree grid resolution using a Behrmann equal-area projection. Richness plotted in 32-quantile spectrum from highest in red to lowest in blue. Legend values indicate maximum, median and minimum gridded species richness.

(a)

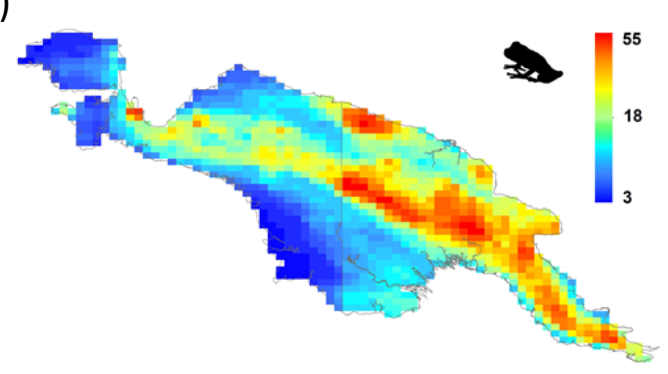

(b)

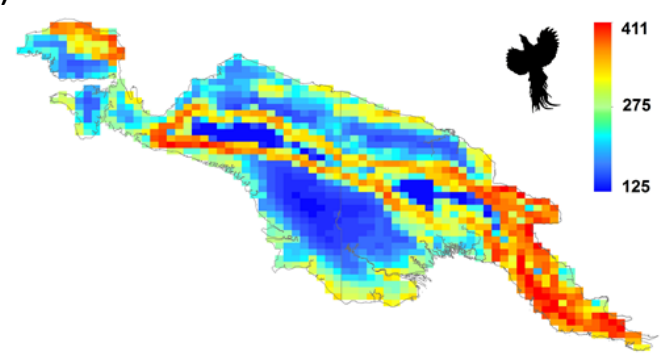

(c)

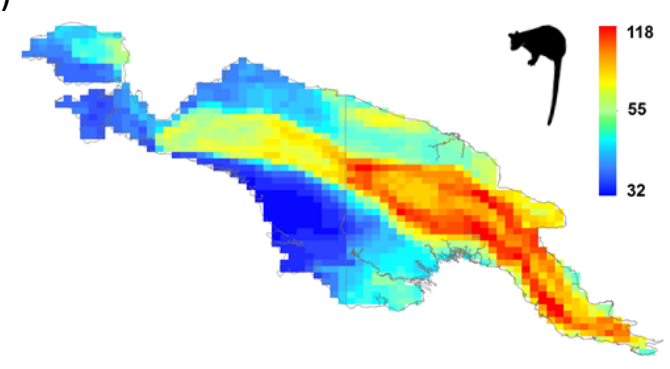

(d)

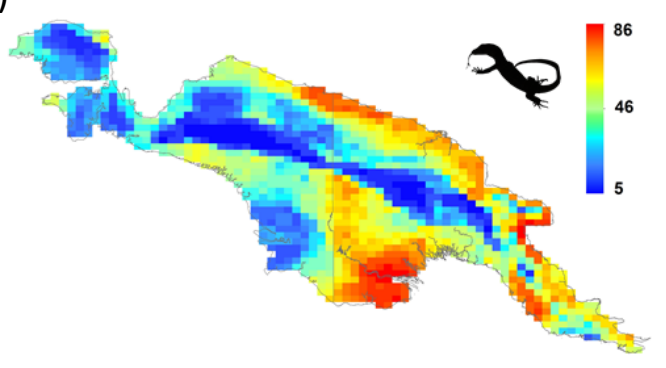

(e)

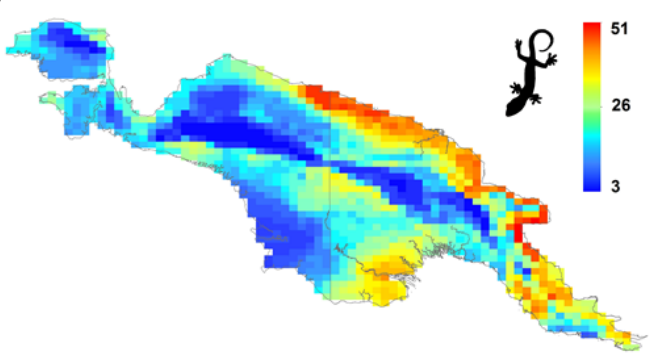

(f)

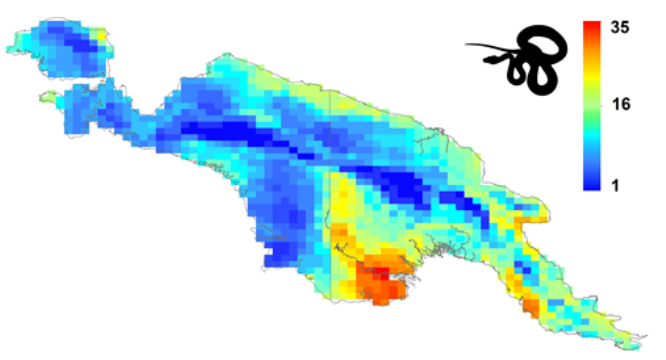

